\title{
Petition and Repression in China's Authoritarian Regime: Evidence from a Natural Experiment
}

\author{
Stan Hok-wui Wong and Minggang Peng
}

China has established a petition system to elicit information about grievances. However, the petition system may have perverse effects because it also reveals to the center the failure of local-level officials to resolve those grievances. Anecdotal accounts suggest that local officials have incentive to silence petitioners, often with the use of repression. In this article we study whether non-regime threatening petitions would provoke local governments' coercive response. To tackle the endogenous relationship between petition and repression, we take advantage of a natural experiment afforded by a change in hydroelectricity policy in China. In particular, we use provincial hydropower outputs as an instrument to identify citizen petitions. We find that citizen petitions significantly increase a province's spending on its repressive apparatus. The results suggest a paradoxical outcome of China's petition system: while it may help reduce the national authority's use of repression, it has caused an explosion of repression within the authoritarian system as a whole. KEYWORDS: authoritarian politics, Chinese politics, contentious politics, petitions, political repression

By 2005, Chen GuangCheng had BeCOME A HOUSEHOLD NAME IN his village in the Shandong province of China. The reason was not so much about this blind man's awe-inspiring pursuit of legal studies as it was about his heroic legal activism. He had filed a lawsuit on behalf of a group of aggrieved women from his village against the local government for carrying out forced abortions in an attempt to meet birth quotas related to the one-child policy. Soon after filing the case, he was placed under house arrest. In the following year, he was sentenced to a four-year imprisonment for "gathering people to block traffic" (Amnesty International 2010). After the jail term, he was still 
subjected to harsh treatment by local authorities, through harassment and continued unofficial house arrest. In April 2012, Chen managed to escape from his own house and traveled secretly all the way to Beijing. More dramatically, he was able to successfully sneak into the US embassy in Beijing to seek temporary refuge. The Chinese authorities later granted permission, probably reluctantly, to Chen, who soon left China for the United States as a visiting scholar.

Apart from his colorful adventure that brought him to the United States, the tribulations that Chen Guangcheng underwent are actually a familiar story in China today. Countless villagers and citizens alike have experienced the effects of draconian government policies. Some try to voice their discontent through legal means such as petitioning. Yet, what they receive in return is often not redress, but repression by abusive government officials. Remarkably, much of this kind of state-society confrontation occurs between local governments and ordinary citizens. The ordeal of Chen Guangcheng is a case in point. Most of the nefarious abuses that Chen experienced (including unfair trials and illegal detention) as a result of his legal activism were meted out by local authorities of his province.

Why would repression occur mostly at the local level in this single-party dictatorship? Minzner (2009) argues that this phenomenon stems from the top-down control system of local agents. In particular, the enormous authoritarian bureaucracy of the People's Republic of China (PRC) entails an effective system in order to tackle pervasive principal-agent problems. For this reason, the central authorities adopt stringent cadre responsibility systems to evaluate the performance of local officials. Hard targets set by higher authorities and the threat of collective liability deter local officials from slacking on their jobs. Yet this very system also induces local officials to abuse their power; the political pressure of meeting these targets is so great that local officials are willing to do anything to get their jobs done, including the use of repression against citizens who stand in their way.

Cai (2008b) contends that local officials' use of repression may actually reflect a larger institutional arrangement that explains the resilience of the Chinese authoritarian state. In particular, by delegating more policymaking power to local governments, the central government can effectively insulate itself from direct confrontation with society. Although local officials may at times abuse their power, the central government may benefit from this situation by providing ordinary people a grievance redress mechanism through which they 
can lodge complaints against local officials. The petition system in China is a prime example. This system allows the central authorities to present themselves as an umpire who can punish corrupt lowranking officials. In other words, the localization of the state's coercive capacity, together with the petition system, can be considered as an institutional design to improve the central government's political legitimacy, thereby increasing the regime's resilience.

Drawing on petition data in Bulgaria and in China during the 1980s, Dimitrov (2013) suggests that a healthy dose of petitions is conducive to the political survival of a single-party dictatorship, for it signals citizens' satisfaction with the grievance redress mechanism. As he points out, the number of petitions dropped significantly prior to the collapse of the Communist regime of Bulgaria, not because Bulgarians approved of the government, but because they no longer drew much hope from it. China also observed a similar decline in the public's trust in the petition system prior to the Tiananmen incident in 1989. As the regime survived the political crisis, it became more responsive to citizens' complaints, which contributed to a gradual increase in the number of petitions.

Not all China observers agree that a growing number of petitions implies a positive sign of regime resilience. Minzner $(2009,71)$ argues that the Chinese leaders' preferred monitoring system for local officials has contributed to riots, which "undermin[e] their core long-term interest - the stability of their country." Indeed, local unrest has escalated into crisis proportions in recent years. An oftcited example is the ever increasing number of collective resistance incidents. In 1993, only 8,700 cases were recorded nationwide, but the number jumped to 180,000 in 2010 (Fewsmith 2013). If the petition system were truly working, it is difficult to explain why so many Chinese citizens have resorted to collective resistance to make their voices heard.

In this article, we will empirically investigate the extent to which the petition system is able to achieve its intended goal. The fundamental function of the petition system is to allow the Chinese authoritarian state to deal with social grievances in a noncoercive way, in order to hold local officials more accountable to the people and improve the political legitimacy of the central authorities. If this system works, it should reduce state repression. But if what we observe shows that petitions end up provoking more repression by the state, this would suggest that the original purpose of the system is defeated. 
To gauge the effectiveness of the Chinese petition system, we can estimate the correlation between the level of appeals and the level of repression in China. Doing so, however, is likely to yield biased estimates due to a problem of reverse causality. That is, when petitions are few, it may indicate that the population is generally satisfied with the regime. However, it may also indicate a level of repression that is so high that few would have the courage to make their grievances heard, no matter how legitimate their causes are. In an authoritarian regime, the true sentiment of the population is often unobservable. Since this important factor cannot be controlled, we are likely to suffer from an omitted variable bias in estimating the correlation between petition and repression.

We tackle the problem of reverse causality by taking advantage of a policy change in the country. China's energy composition has been heavily skewed toward fossil fuels, which are notorious for contributing to environmental pollution. To meet the ever growing demands of energy consumption while simultaneously reducing the negative environmental externalities of fossil fuels-generated energy, the Chinese government, since the mid-1990s, has been determined to increase the share of renewable energies in the country's energy composition. Thus, the development of hydropower has become a national policy target. The central government has encouraged provincial governments to tap into their water resources by building more hydropower stations. In many respects hydropower is no doubt cleaner energy when compared with fossil fuels, but it is not completely pollution-free. As will be discussed in detail in the following section, dam construction could exact a heavy toll on the environment, and the resulting environmental hazards in turn generate public discontent and grievances.

We exploit the fact that not all provinces could respond to the central government's call for hydropower development due to the differences in their natural endowment; only provinces with a sufficiently large river system and a steep river gradient are able to support hydropower. In other words, a province's hydropower potential offers a natural experiment to study the effects of grievance appeals on repression, for it provides a source of exogenous variation seen in the change of water-pollution protests through the channel of dam construction. Using provincial hydropower outputs as an instrument for water-pollution protests, we find that provincial governments respond to citizen petitions with more expenditure spent on the coercive apparatus under its control. In addition, the form of petition also 
matters. Bureau-visit petitions tend to induce more resources spent on repression than do letter-writing petitions.

A caveat is in order. In this article we study whether the petition system, which is intended to relieve social grievances, turns out to provoke repression at the local level. Whether the local repression succeeds in reducing petitions is not our focus, although we believe that this is an important question, as it would reveal the effectiveness of China's coercive apparatus, or even its state capacity. Owing to the limited scope of this article, we will leave the investigation into this important question for future research.

The organization of the article is as follows. In the next section, we discuss our theoretical motivation. We then derive several empirical implications, followed by a description of our research design and empirical results, and finally our conclusions.

\section{Theoretical Motivation}

To an authoritarian regime, repression is a two-pronged sword. On the one hand, it can use repression to crush dissent and protest, signaling its power and nipping any threat to regime survival in the bud. On the other hand, repression may backfire on the regime. Studies show that repression often spurs protest by fueling existing grievances (Francisco 1996; Lichbach and Gurr 1981; Ziegenhagen 1986). In addition, repression isolates the dictator. As Wintrobe (1998) points out in his exposition of the "dictator's dilemma," when no citizen dares to protest for fear of a dictator's repression, the dictator is no longer able to distinguish between loyalists and potential challengers. Failing to identify potential threats, the dictator exposes himself to more unknown political risks.

There are two common strategies for an authoritarian regime to solve this dilemma. One is to use co-optation along with repression. For instance, the regime can invite the opposition elite to join quasidemocratic institutions such as the legislature, so that the regime can identify and encapsulate potential challengers (Gandhi and Przeworski 2007; Geddes 2005; Magaloni 2006). Despite the co-optation functions of quasi-democratic institutions, only a small number of dissidents would ever be allowed to sit in those institutions. The vast majority of the citizens who face everyday injustices still have little recourse against the regime. When grievances run deep, they may have to take the risky route of protest and demonstration to show their dissatisfaction. In response to citizen protests, the authoritarian 
regime may step up its repression. Doing so, however, is risky, for it may fuel more grievances. Rasler (1996) uses the case of the Iranian revolution to show that repression deters protest in the short run, but stimulates protest in the long run. In addition, punishing whistleblowers is sometimes counterproductive because whistle-blowers are the ones who provide valuable information for the authoritarian regime to evaluate the performance of its own officials.

For this reason, to solve the "dictator's dilemma," authoritarian regimes often employ a second strategy, which is to use coercion selectively: repress antiregime protests, but redress non-regime threatening civilian grievances. Many authoritarian regimes choose not to exercise repression indiscriminately. While these regimes seldom hesitate to suppress antiregime protests, they rely on institutional mechanisms to address nonpolitical grievances. For example, Moustafa (2007) shows that Egypt under Sadat created an institutionally autonomous constitutional court as a way to discipline lowerlevel officials, and the court often ruled against the interests of the state, especially in cases involving foreign capital. The authoritarian regime of Mexico under the Partido Revolucionario Institucional also established the amparo trials that allowed citizens to check abusive local officials (Magaloni 2008). In Indonesia, the former dictator Soeharto set up a specialized administrative court to curb lower-level corruption (Bourchier 1999). China, in addition to its courts, has a distinctive appeal system known as xinfang, through which citizens can petition bureaucratic agencies or higher government authorities to redress their grievances associated with official misdeeds (Paik 2012).

A successfully enforced appeal system is likely to enhance the legitimacy of the regime. But maintaining a successfully enforced appeal system is not easy. In theory, by separating social grievances from antiregime protests, authoritarian leaders can identify potential challengers while giving proper treatment to public discontent. In practice, however, proper treatment often implies that someone within the ruling elite (other than the national leaders) has to take the blame and be penalized. Few authoritarian leaders-national or local — can tolerate being openly challenged by citizens. If the lowerlevel officials are unwilling to see their power hamstrung by citizen activism, the effectiveness of the appeal system is called into question. After all, it is these officials who are responsible for the everyday operation of the authoritarian government. One cannot evaluate the effectiveness of the appeal system without taking into consideration the reaction of such officials. 
Would lower-level officials in authoritarian regimes voluntarily tie their own hands and accept punishment as a result of citizens' complaints? Or would they behave in the same way as the national leaders, namely, ruthlessly repressing voices of dissent that threaten their own political survival? In this article, we examine whether and how lower-level officials in China systematically mobilize their repression apparatus in response to citizens' appeals, which are neither targeted at national leaders nor considered regime-threatening.

\section{Background}

The unit of analysis in the current study is the provincial governments in China. As previously mentioned, although provincial heads lead a subnational government, the challenges related to their political survival are in many ways similar to those of an autocrat's holding a national office. To understand their behaviors and concerns, we discuss in this section the power structure of the Chinese political system that encapsulates these provincial leaders. We also examine how this power structure shapes the opportunities and constraints for citizens to defend their interests, especially when these are at odds with the local leaders'.

The Chinese government has multiple layers in its formal administrative structure. Below the central government lie the provinciallevel governments, which consist of twenty-two provinces (excluding Taiwan), five autonomous regions, and four municipalities. ${ }^{1} \mathrm{~A}$ provincial government is officially led by a governor. In reality, the governing power is shared between the governor and a provincial party secretary (Lieberthal 1995). For simplicity, we do not distinguish between a governor and a provincial party secretary when we refer to provincial leaders, unless such a distinction is necessary.

Provincial leaders have the power to influence a wide range of local policies. This is in part because China has a decentralized fiscal system, under which provincial governments are allowed to retain a substantial portion of government taxes in addition to receiving fiscal transfers from the center (Zhan 2009a; Jin, Qian, and Weingast 2005; Tsui and Wang 2004; Wang 2005). Provincial governments are responsible for the provision of a host of public services, including education, health services, and public security. The 1994 fiscal reform has increased the center's power over the collection of provincial taxes. Facing dwindling local resources, provincial governments find themselves increasingly dependent on the center's fiscal transfers. But such transfers often fail to cover a shortfall in rev- 
enue. For this reason, some provincial governments need to raise extrabudgetary incomes (Zhan 2009b). ${ }^{2}$

The central government is able to exert a strong influence over decisionmaking at the provincial level because it controls not only the level of fiscal transfers, but also the appointment power over the heads of provincial governments (Huang 1999). If provincial leaders would like to get promoted to a higher level of office, they have to demonstrate their ability to complete policy targets set by the central government. In general, local leaders in China are expected to achieve two fundamental policy goals: (1) to maximize the local GDP and (2) to maintain social order (Edin 2003). As expected, these two goals do not always go hand in hand. Although it is argued that the concern for GDP growth often trumps the concern for social stability (Goldstein 1994; Tsui and Wang 2004; Whiting 2006), failure to contain social unrest can write off other policy merits or even lead to removal (Edin 2003). The abrupt job transfers of Tung Chee-hwa (the former chief executive of Hong Kong) and Wang Lequan (the former provincial party secretary of Xinjiang) are cases in point (Wong and Takeuchi 2013). From the center's perspective, removing highly unpopular local officials is not necessarily a bad option, especially when doing so can improve its own image and political legitimacy (Cai 2008b).

Nonetheless, Chinese citizens need to be very careful when negotiating their rights with the authorities. The first lesson that they have to learn is not to cross the line. Antiregime activities are absolutely counterproductive, but exposing the malfeasance of a specific government agency or a local official is acceptable. As O'Brien and $\mathrm{Li} \mathrm{(2006)}$ point out, even Chinese peasants are aware that the state power of China is fragmented; the interests of the central government and local cadres may not necessarily converge. Local officials may not implement central policies as intended, especially when such policies undermine these officials' own interests. If citizens find themselves victimized by the local officials' dereliction of duty, they have the right, morally and officially, to resist the policies at issue. For instance, local cadres who hire gangsters to punish peaceful petitioners with legitimate demands transgress the official regulations. ${ }^{3}$ Victims in this case have the right to expose the local cadres' wrongdoing. At times, the "rightful resisters" even employ official rhetoric (with vocabulary such as "revolution," "serving the people") to inveigh against problematic local cadres. The key is that as long as they articulate their case within the officially acceptable boundary, 
they stand a chance to win the political support of the higher authorities and, hence, a redress of their grievances.

Yet in practice, how would Chinese citizens make their cases heard? They are not completely defenseless against government abuse. The Administrative Litigation Law, which was promulgated in 1989 , provides citizens a legal basis to sue the local state for official malfeasance. In reality, however, bringing charges against local officials is not considered a viable option for many. Different surveys show that only 10 percent of the respondents would resolve conflicts with government agencies through the court (O'Brien and Li 2004). A household survey conducted by Michelson (2007) also finds that those who appeal to the official justice system tend to be politically well-connected. These results support the general view that local courts in China are not independent of the influences of local governments (O'Brien and Li 2004; Peerenboom 2003).

A more common strategy of contention is to make use of the "letters and visits" (xinfang) appeal system. As its name suggests, complainants can send letters or pay a visit to administrative agencies for intervention and redress. For fear that local administrative agencies are tied with the local officials under complaint, citizens are allowed to "visit higher-level authorities" (shangfang). For example, there is a National Complaints Bureau whose primary job is to receive petitions against local officials from all over the country. From the central government's point of view, the installation of the petition system serves its political interests in a similar way to the rural elections. The system protects the regime's legitimacy by diverting public dissatisfaction from the central to local governments (Cai 2008b).

However, one major consequence of the petition system is the intensification of the confrontation between citizens and local governments, which arises for two reasons. The first is related to local officials' career concerns. As discussed, the promotion prospects of local officials depend on their fulfillment of a set of responsibilities assigned to them by the central government. Petitions put the job prospects of a local official in jeopardy because they signal poor administrative performance. In addition, maintaining social stability is one of the most important job responsibilities for local officials (Cai 2008b; Edin 2003). Poor job performance might not be a fatal error, but the very failure to prevent the petitions from being lodged and then escalating indicates a local official's inability to solve "internal conflicts among the people" (renmin neibu maodun). 
Because of these career concerns, local officials often resort to ruthless means to prevent local citizens from contacting higher authorities. For example, in 2002, several villagers from the Henan province appealed to authorities at the county, city, provincial, and central government levels demanding authorities to put a stop to misdeeds of village officials in village finance and elections. They were eventually arrested by the county government, with five villagers sentenced to five-year imprisonments (Xinhua Net 2003b). In another example, a villager from a Zhejiang county went to Beijing to file a petition against local county leaders, who were engaged in illegal fines, brutal extortion, and forced eviction all carried out on the pretext of implementing the family planning policy. He ended up being seriously beaten by local officials (Radio Free Asia 2011).

The second point of conflict between citizens and local officials lies in economic interests. To deal with disgruntled citizens, repression is not the only option. Occasionally, local officials are willing to make concessions in order to pacify aggrieved citizens. Cai (2008a), however, points out that local governments are generally reluctant to take this option for various reasons. Chief among them is that backing down may entail a change of policies. When local governments have a high stake in existing policies, such as those involving local economic development, concessions are difficult to make. For example, a major source of conflicts in China today is land disputes. Farmers complain about the loss of their farmland because local governments sell these to property developers. Oftentimes, local governments can earn an enormous profit from the deal. It is therefore difficult for them to change their policies, despite the farmers' complaints. In addition, pacifying the disgruntled citizens may involve monetary compensation. Under a tight fiscal budget, local governments may also lack the financial means to address petitioners' grievances.

When concessions are difficult to make or when citizen resistance is deemed too threatening, local officials often show no hesitation in cracking down on petitions. Despite the existence of the Regulations on Letters and Visits, which clearly stipulate that "no organization or individual may retaliate against letter-writers or visitors," in practice, petitioners are often in a weak position to properly defend themselves against the retaliation of local officials. There are cases where lower-rung officials even hire thugs to brutalize activists (Cai 2008a). 
This is not to say, however, that coercion exercised by local governments is without cost. When the confrontation between a local government and residents goes out of control or when the crisis surfaces in the national media, the central government may step in and punish the officials involved. Nevertheless, as Cai (2008a) points out, intervention from the central government is the exception rather than the rule. Part of the reason is that the central government needs to consider the negative side effects of sacking a local official. For example, doing so would demoralize other local officials who may become reluctant to carry out the central government's policy that is likely to meet local resistance. In addition, as Tarrow (2011) suggests, "one of the most remarkable characteristics of collective action is that it expands the opportunities of others." The central government is concerned that if officials could be easily removed by protest, more collective resistance would emerge.

The above discussion suggests that provincial leaders in China face similar challenges confronting typical dictators. First, their political survival is not risk-free, and one major source of the risk is citizen complaints. Second, they have a coercive apparatus such as local public security forces at their disposal. They sometimes deploy this apparatus to suppress citizens' demands. Third, their unconditional use of force may backfire, as it may fuel public resentment and stimulate resistance. Massive social unrest can lead to provincial leaders' downfall because of the disciplinary actions that higher authorities can mete out against unpopular local officials.

\section{Empirical Implications}

The foregoing analysis suggests that while the central government has an incentive to use the petition system to hold local officials accountable, thereby improving its own political legitimacy, the system may well fall short of its intended goal due to the resistance of local officials. Knowing that citizens' complaints may have an adverse impact on their career, local officials have an incentive to deploy their coercive apparatus to clamp down on "trouble-making" citizens. We can therefore derive the following testable empirical implications:

Implication 1: A provincial government's use of repression would increase as the number of petitions filed by the province's residents increases. 
A large number of petitions suggests that there are many affected individuals. In order to pacify a large number of aggrieved citizens, it would necessitate a radical change of policy. When this policy is intended to enhance local economic growth, the provincial government would be reluctant to make the change, as doing so might cut deep into the profits guaranteed by the original policy. In addition, redressing their grievances is likely to involve a huge sum for compensation, which discourages the local government from making concessions. Perhaps more importantly, the more people share grievances about the local government, the higher the risk of large-scale collective resistances. On the contrary, when petitions are few, compensation would be cheaper. Or the local government can simply ignore the demands of the coterie of petitioners without worrying about social and political repercussions.

When neither reversing policies nor paying compensation is an option to a provincial government, and when the number of petitions becomes too large to ignore, we should then expect that the provincial government would escalate its use of repression to suppress dissent. It is important to note that coercion is not necessarily employed to deal with petitioners per se, as some aggrieved individuals may take actions other than making a formal petition to demand changes. In this regard, the number of petitions may serve as an indicator of public discontent about a provincial government's policy.

Implication 2: High-intensity petitions would provoke increased use of repression by the provincial government more than low-intensity petitions would.

A high intensity of petitions signals that aggrieved individuals are willing to take bolder measures to make their cases heard, such as traveling longer distances to appeal to higher authorities and reaching out to the media. These attempts, when successful, can produce adverse impacts on the implementation of government policies, let alone on the reputations and career prospects of the officials involved. Local officials therefore have a strong incentive to use force to contain high-intensity petitions and to prevent a dispute from escalating into crisis proportions.

Implication 3: The national government's use of repression at the provincial level would not increase as a result of provincial petitions. 
Provincial governments do not monopolize the control of local coercive apparatus. National authorities also have the power to deploy armed units at the local level. But because the job performance of national leaders does not hinge upon the social stability of a particular province, local petitions should have no bearing on national authorities' use of repression at the provincial level.

\section{Methodology}

\section{Operationalization}

The centerpiece of the coercive apparatus of a local government in China is the public security police (PSP or gongan), which is under the administration of local authorities. To operationalize the use of repression at the local level, we use local governments' expenditure on the PSP as a share of the province's gross domestic product (or as a share of the provincial government's total expenditure) as our dependent variable. For data sources, see Appendix B.

Some studies measure repression levels by examining governments' responses to protest such as the number of arrests and casualties. In authoritarian regimes, this kind of measure is problematic because whether there is a protest at all in the first place is conditioned on how repressive the government is. Using a government's expenditure on internal security should capture the multifaceted nature of repression, which involves both ex pose controls as well as ex ante preemption. ${ }^{4}$

This is not to say, however, that a local government's security budget is dedicated solely to purchasing weapons or physical equipment. The budget may include other items such as hiring police officers and administrative expenditure of the related departments. In other words, not every single item in a local government's security budget is directly applied to the suppression of citizen protests. Although the internal security expenditure of a local government may be an imperfect measure of the actual extent of local suppression, it should reflect the capacity building of the government's repressive power, which is in turn positively correlated with the demand of repression at the local level.

The variable of interest in our study is popular grievance measured by two variables of petitions related to the issue of water pollution: (1) the number of letters and (2) the incidence of bureau visits (pici) received by the Environmental Protection Bureaus (EPBs) of each 
province. ${ }^{5}$ We lag these variables by one period because it takes some time for petitions to affect a government's coercion spending.

Consider the testable implications. If Implication 1 is correct, we should expect to see a positive relationship between a provincial government's repression spending and the number of petition letters or the incidence of bureau visits. If Implication 2 is correct, we should expect to see that bureau visits carry a larger effect than letterwriting in provoking a provincial government's repression spending, because visiting a government bureau is more confrontational than merely sending in a complaint letter. If Implication 3 is correct, we would expect to see that only the coercive apparatus under a provincial government's control would observe an increase in its expenditure as a result of rising local petitions.

\section{Estimation Strategy}

Simply regressing the dependent variable on the variable of interests may give biased estimates. This is because petitioning in an authoritarian regime like China is not risk-free. Perceived threats of retaliation by the local officials under complaint are likely to deter victims from pursuing redress. In other words, our estimation is beset by the problem of reverse causality. The variable of interest, which is endogenous with the dependent variable, should be biased downward as the threat of retaliation is expected to discourage ordinary citizens from petitioning. Econometrically, this implies that the ordinary least squares (OLS) estimates, which take no account of endogeneity, would be smaller than the true effect.

To tackle the problem of reverse causality, we need to find an instrumental variable for a province's petitions involving water resources, which is our variable of interest. A valid instrument should be correlated with the endogenous variable of interest, while simultaneously being uncorrelated with the dependent variable. We identify such an instrument by taking advantage of a policy change in China's energy policy. Our instrumental variable (IV), which is a province's hydropower output, will be discussed below.

Hydropower in China. The development of hydropower has become a national policy in China of late. Dam construction projects have proliferated since the early 1990s. The construction of the Three Gorges Dam, the world's largest dam, gave further impetus to the zeal of hydropower. The country currently has 87,000 dams (Nanfang Zhoumo 2011). The Ninth Five-Year Plan, passed in 1996, encouraged provincial govern- 
ments to develop hydropower of all scales. ${ }^{6}$ Between 2002 and 2007, the so-called Tenth Five-Year Period, the output of hydropower, together with other renewable energies, increased at a yearly rate of 10 percent. In comparison, the petroleum outputs grew at 2 percent per annum in the same period. In 2007, the National Development and Reform Commission issued an energy development plan for the Eleventh Five-Year Period, during which hydropower was given top policy priority. ${ }^{7}$ There are many reasons for the development of hydropower. Here we highlight three. First, China needs to secure a stable and growing supply of energy to sustain its rapid industrialization and urbanization processes. Second, China has sizable untapped hydropower resources. The country is currently exploiting no more than 30 percent of its hydropower potential (Mertha 2008). Finally, hydroelectricity is said to generate no carbon emission. The geographical distribution of recent hydropower outputs by province is displayed in Figure 1.

Having no carbon emission does not mean zero pollution, however. Hydropower requires the construction of dams, which may lead to myriad environmental problems. A dam is designed to regulate the flow of water in order to turn the turbines. This would inevitably

Figure 1 Hydroelectricity Output by Province, 2009

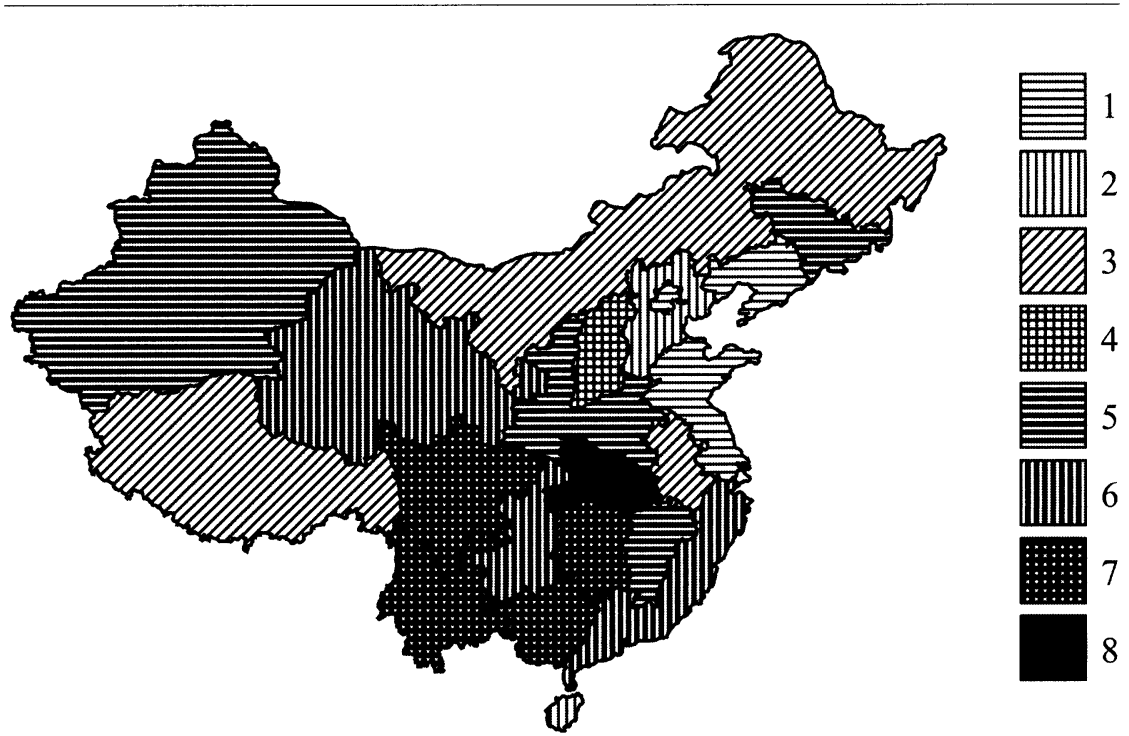

Note: The unit is $\log 10^{8}$ kilowatt hour $(\mathrm{kWh})$. 
reduce the speed of water flow along a river. A potential problem associated with a slowdown is deterioration in water quality (McCully 1996). This problem is particularly salient in China, where many rivers have already been seriously polluted by industrial plants. ${ }^{8}$ Adding more dams significantly reduces the rivers' ability to dilute the pollutants, especially in times of drought (Economy 2004).

The creation of an artificial reservoir behind the dam aggravates the above problem, as the reservoir would trap most of the nutrients carried by the river. The nutrition-rich reservoir is a hotbed of algae, which also feed on effluent and sewage. Algal blooms would create an unpleasant smell, and more importantly, render the water unsuitable for human use (McCully 1996). The nutrition also provides a favorable condition for the proliferation of invasive aquatic plants such as water hyacinth. Recent reports show that this floating plant has colonized different parts of the Pearl River Delta, clogging fishing boats' turbines and killing other aquatic organisms by blocking sunlight.

While the process of generating hydroelectricity is believed to emit little carbon dioxide, the creation of a reservoir may. Vegetation submerged in the reservoir would become rotten, and release greenhouse gases such as methane and carbon dioxide. The decomposition of the submerged vegetation, which may take decades to complete, would deoxygenate the body of water, killing living organisms and leaving the water undrinkable (McCully 1996). The water level of the reservoir also requires a constant adjustment to prevent floods. The fluctuation of water level weakens the slopes along the reservoir banks, heightening the risk of landslide. A quarter of the 16 million people living in the reservoir area of the Three Gorges Dam needed to be resettled elsewhere because of the landslide risk (Stone 2008). In their study of the distributional effects of irrigation dams in India, Duflo and Pande (2007) also provide empirical evidence showing that dam construction leaves adverse economic impacts on the districts where the dams are built.

A dam would also bring undesirable impacts on the river's natural habitat. It would disrupt the aquatic ecosystem such as water temperature and salinity, endangering the river's living organisms. In addition, the dam segments the river such that some fish species are no longer able to reach their spawning sites. In fact, damming is an important factor contributing to the extinction of one-third of the fish species native to the Yellow River (Economy 2007). An immediate economic impact is a decline in fishermen's catches. 
Damming is associated with other environmental problems such as river and coastal erosion, which can lead to human displacement (Fearnside 1988), and in some cases the demolition of communities. In sum, the development of hydropower is more than erecting a mud wall. It would leave enormous impacts not only on the natural environment, but also on the inhabitants of the affected region.

Figure 2 compares water-pollution petitions with petitions involving other types of pollution in three periods. As may be seen from the figure, petitions related to water resources are consistently ranked third. Although the share of letter-writing petitions related to water resources slightly decreases over time, the proportion of waterrelated bureau-visit petitions remains largely constant.

The foregoing discussion is not to dispute the benefits of hydropower vis-à-vis other types of energy. It is only intended to

Figure 2 Environmental Petitions by Type

1996 Letter-Writing Petitions

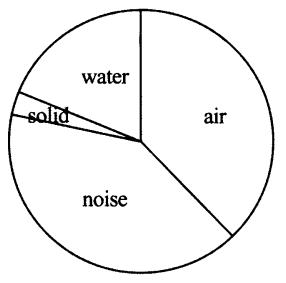

2000 Letter-Writing Petitions

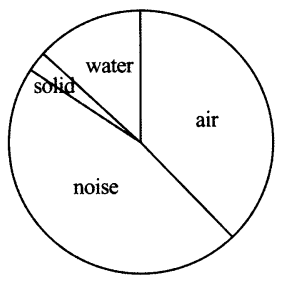

2006 Letter-Writing Petitions

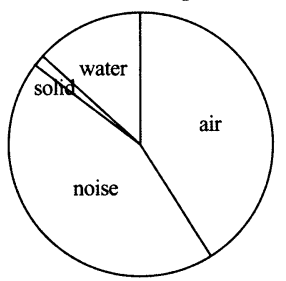

1996 Bureau-Visit Petitions

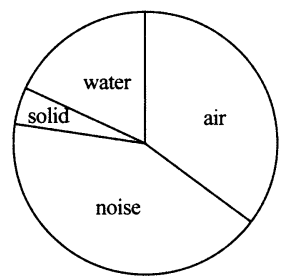

2000 Bureau-Visit Petitions

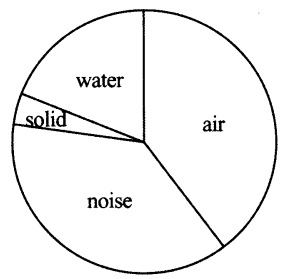

2006 Bureau-Visit Petitions

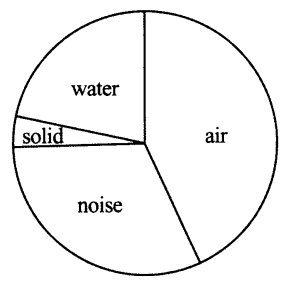


highlight the potential environmental hazards and social repercussions associated with the development of hydropower. The downside of hydropower development often manifests itself in the rise of social grievances. The construction of the Three Gorges Dam, which is located in the Hubei province, is a case in point. The construction of this mega dam project entailed the relocation of 1.39 million people (Xinhua News Agency 2010) and the destruction of two cities, 277 townships, and 1,680 villages (General Office of the State Council 2006). Owing to the installation of the Three Gorges Dam, which began to operate (in partial capacity) in 2003, the province's hydroelectricity output has increased significantly. So, too, did the petitions related to water pollution, as may be seen in Figure 3. In fact,

Figure 3 Three Gorges Dam and Water-Pollution Petitions: The Case of Hubei

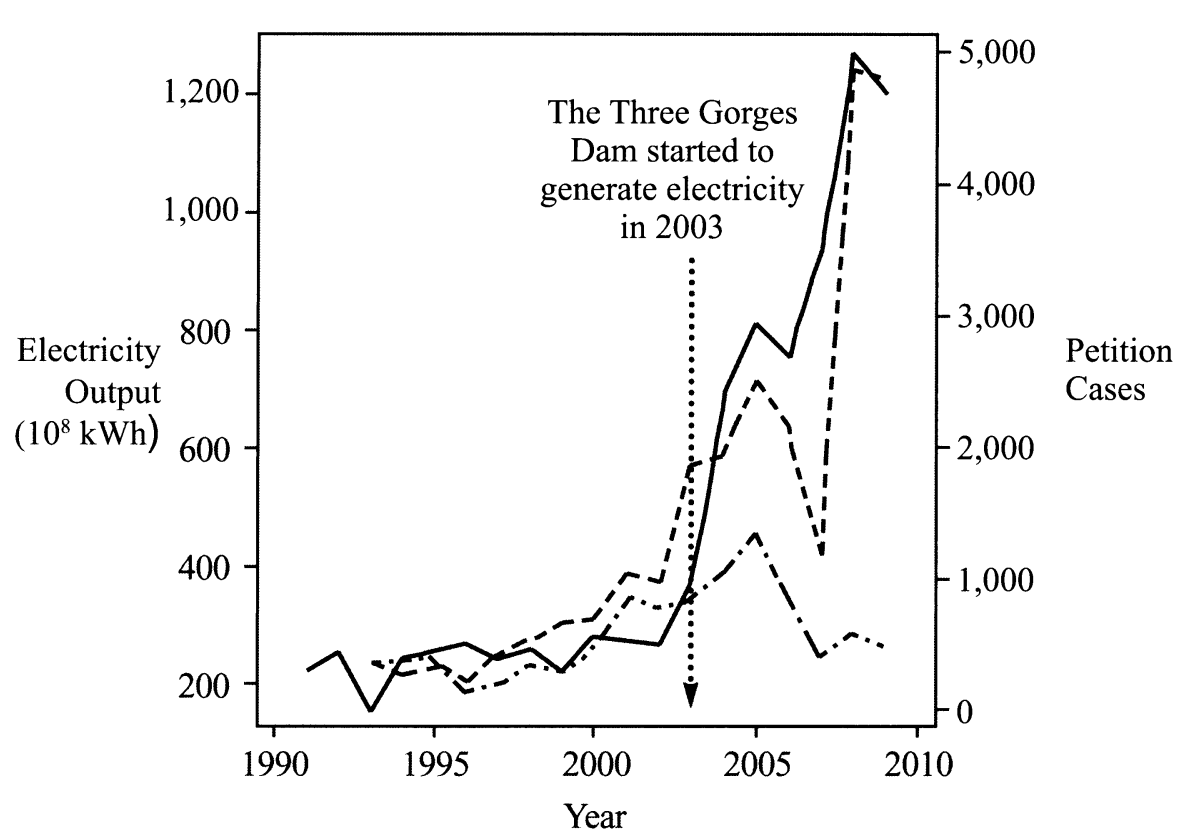

Notes: The hydroelectricity output of the Hubei province is denoted by the solid line (leftscale). Letter-writing petitions and bureau-visit petitions received by the environmental protection bureau of the Hubei province are denoted by the dashed and dot-dash lines (right scale), respectively. 
the number of petitions began to rise in the mid-1990s, coinciding with the dam's construction, which began in 1994.

Local leaders often ignore the above environmental risks because the potential benefits of hydropower are simply too great to resist. First, the development of hydropower has become a national target. It is not easy for provincial leaders to resist the central government's policy. Second, dams can help with flood control. Third and more importantly, hydropower is good for the local economy. Dam construction creates jobs, and the generated hydroelectricity can power other industrial activities. In addition, provincial governments, who are typically shareholders of the hydroelectric power plants (Magee 2006), can sell the unused hydropower to other provinces for profit (Mertha 2008). Dam construction can also elevate the river tonnage, supporting the navigation of larger vessels. In fact, one of the advertised advantages of the Three Gorges Dam is that it can link the Chongqing municipality to the ports in the coastal area, and hence to the world (Xinhua Net 2003a). For these reasons, the official rhetoric often equates hydropower to a fast track to modernization and poverty alleviation.

Furthermore, other energy options could also yield negative externalities to the environment (carbon emissions from fossil fuels and radioactive waste from nuclear power). In other words, the claim that the environmental cost of hydropower would necessarily outweigh the socioeconomic benefits that ensue remains debatable. There is also no compelling evidence to expect ex ante that relying on other energy sources such as coal would necessarily inflict less harm on the environment.

Note that hydroelectricity output is not dependent on a province's development level or infrastructure capacity, which may be correlated with repression. ${ }^{9}$ The reason is fourfold. First, although economic development increases the overall demand for energy, it would not increase the demand for a particular type of energy such as hydropower. What affects a province's energy composition is its natural endowment, which determines how efficiently it could produce a certain kind of energy. Second, as mentioned, local governments can sell unused hydroelectricity to other provinces for profit. As such, even less-developed provinces have an incentive to tap into their hydroelectricity potentials.

Third, the cost burden of developing hydropower is often shouldered by other entities than local governments. Typically, a specific company will be set up to undertake a hydropower development project. The major shareholders of such companies are national state- 
owned power companies, national state-owned banks, and some large companies, though provincial state-owned investment companies and local governments may also have a stake in these companies. For instance, Huaneng Lancang River Hydropower Company Limited is responsible for the construction and operation of hydropower facilities in the Lancang River of the Yunnan province. As its name suggests, this company is a regional subsidiary of the national stateowned electricity enterprise, China Huaneng Group, which was set up by the State Council. In addition to funding from national stateowned enterprises (SOEs), the central government also provides financial subsidies ${ }^{10}$ or tax incentives ${ }^{11}$ to hydropower projects. In other words, poor provinces should be able to take advantage of their hydropower potentials, despite their relatively weak infrastructure capacity.

Finally, unlike building bridges, which can be done virtually anywhere, the development of hydropower requires specific natural endowment that is not available in all provinces. The geographical distribution of hydropower outputs shown in Figure 1 attests this point. Not all coastal provinces, which tend to be wealthier, produce large hydropower outputs (for example, the Jiangsu province). By contrast, inland provinces such as Yunnan that are less developed can have high hydropower outputs. Part of the reason is that many coastal provinces lack a steep river gradient to support the development of hydropower.

In summary, the only systematic factor that deters provinces from pursuing the great leap forward in hydroelectricity is their own inadequate water resources. Not all provinces have a river system that supports dam construction. Whether a province has an exploitable river system is determined by its natural landscape, rather than by the volition of its local leaders or the developmental level of the province. The uneven distribution of river systems, therefore, provides a source of exogenous variation in environmental protest related to water resources, for it is uncorrelated with local governments' preference for, or capability of, repression. Hydropower outputs would affect local governments' repression not because provinces that have hydropower potentials are inherently repressive, but because the development of hydropower would escalate petitions due to dam construction. The construction in turn may cause problems such as environmental degradation and resettlement conflicts, thereby provoking local governments' repressive responses. 
We lag hydroelectricity output by one year to capture its time lag effect on petitions.

\section{Empirical Specifications}

Our baseline specification is OLS. OLS does not take into account the endogenous relationship between petition and repression. To tackle the reverse causality problem, we apply two-stage least squares (2SLS), using hydroelectricity output as an instrument for water-pollution petitions.

The baseline OLS specification is as follows:

$$
\begin{aligned}
y_{i t}= & \beta_{0}+\beta_{1} \log \text { GDP per capita } \\
& +\varphi w_{i t-1}+\beta_{2} \text { Population Density }_{i t}+\gamma_{t}+\varepsilon_{i t},
\end{aligned}
$$

where $y_{i t}$ is province $i$ 's PSP expenditure at time $t, \beta_{1}$ and $\beta_{2}$ are the parameters of the control variables, $\varphi$ is the coefficient on the variable of interest $w$ at time $t-1$, where $w$ refers to letter-writing petitions (bureau-visit petitions) related to water pollution, $\zeta_{i}$ represents a province-level fixed effect, $\gamma_{t}$ represents a year fixed effect, and the error term $\varepsilon_{i t}$ is assumed to be independent and identically distributed.

As its name suggests, the 2SLS regression involves two steps. In the first stage, we regress the endogenous variable, letter-writing petitions (bureau-visit petitions), at time $t-1$, on other exogenous variables plus the instrument, hydroelectricity output:

$$
w_{i t-1}=\delta_{0} z_{i t-2}+\mathbf{x}_{\mathrm{it}}{ }^{\prime} \boldsymbol{\delta}_{1}+\eta_{i t},
$$

where $\delta_{0}$ is the coefficient on the instrument $z_{i t-2}, \boldsymbol{\delta}_{1}$ is a vector of coefficients on the control variables $\mathbf{x}_{\mathrm{it}}$ shown in Equation 1 , and $\eta_{i t}$ is the error term assumed to be independent and identically distributed and uncorrelated with $\mathbf{x}_{\text {it }}$ and $z_{i t-2}$.

In the second stage, we substitute Equation 2 into the causal relation of interest:

$$
y_{i t-1}=\theta_{0} \hat{w}_{i t-1}+\mathbf{x}_{\mathbf{i t}}{ }^{\prime} \boldsymbol{\theta}_{1}+v_{i t},
$$

where $\hat{w}_{i t-1}$ is the fitted value of $w_{i t-1}$ computed from Equation 2, $\theta_{0}$ and $\boldsymbol{\theta}_{1}$ are coefficients for $\hat{w}_{i t-1}$ and $\mathbf{x}_{\mathrm{it}}$, respectively, and $v_{i t}$ is an error term assumed to be independent and identically distributed. 


\section{Control Variables}

The baseline model as in Equation 1 does not control many factors that may affect the spending on law enforcement. In order to reduce the risk of omitted variable bias, we provide an alternative specification that includes a host of control variables. First, economic Growth (measured by the annual change in the province's GDP) improves the lot of local residents, which may reduce social discontent as well as law enforcement expenditure. Population Size matters, as populous provinces require more resources to maintain law and order. Similarly, provinces with a high Lagged Crime Rate should spend on more law enforcement. Because both unemployment and inflation can breed social discontent, which in turn affects our dependent variable, we control for Lagged Unemployment Rate, Annual Change in the Consumer Price Index (CPI). Ethnic conflicts have become a major source of social instability in China in recent years, which would have a direct impact on local governments' investment in the coercive apparatus. Hence, we include Minority Population Share as a control.

A province's spending on law enforcement should also be correlated with provincial leaders' incentive. As mentioned, failure to maintain social stability has a detrimental effect on local leaders' careers. Provincial leaders may have an incentive to invest in law enforcement to avert social unrest. However, their incentive is likely to change over time. For instance, in the early years of their tenure, the pressure of maintaining social stability may be higher. We therefore include Tenure of Governor and Tenure of Secretary, which measure the years in office of a provincial governor and secretary, respectively. We also include Transition of Governor (Transition of Secretary), which is a dichotomous variable given a value of 1 if a province experiences a change of governor (party secretary) in a given year, and 0 otherwise. Politburo Governor and Politburo Secretary are also dichotomous variables, which take a value of 1 if the provincial governor or party secretary sits on the Central Politburo of the Chinese Communist Party and 0 otherwise. The reason for including these two variables is that when provincial leaders are able to concurrently occupy a national-level political office, their job performance pressure at the provincial level should be relatively weaker.

Local leaders in China have been anxious to attract foreign direct investment (FDI) to improve the local economy as well as their job performance. Incoming FDI, however, has become a major source of labor disputes, which have risen at an exponential rate in recent years 
(Gallagher 2011). The proliferation of labor disputes is likely to entail more spending on law enforcement. For this reason, we also control Lagged Foreign Direct Investment in the full regression specification.

Finally, as in the baseline model, we include province and year fixed effects to control for idiosyncratic shocks pertaining to particular years and provinces. Appendixes A and B provide descriptive statistics and data sources of all variables.

\section{Empirical Results}

Table 1 presents both the OLS and 2SLS estimates of the two endogenous variables of interest, which are the letter-writing petitions and bureau-visit petitions. First, consider the OLS results, in the last four columns of the table. The coefficients on our variables of interest show the expected positive sign, suggesting that more petitions lead to more spending on the coercive apparatus of local governments. The effects, however, are statistically insignificant, no matter whether we use Public Security Police Expenditure (PSPE)/ GDP or PSPE/Provincial Government's Total Expenditure (GE) as the dependent variable. This implies that we cannot rule out the possibility that the effects merely occur due to chance. The lack of effect may suggest a downward bias of the endogenous relationship between petitions and repression, as explained above.

To tackle the problem of reverse causality, we apply 2SLS, the results of which are also displayed in Table 1. As may be seen from the table, petitions do have a positive and significant impact on provincial governments' coercive expenditure in both the baseline and full models. This supports Implication 1 that a provincial government would increase its use of coercion when the number of petitions rises. The effects are also of substantive importance. Consider the full specifications. For every 100 petition letters received by the EPB, there would be a 0.008 percent increase in the PSP expenditure share in the province's GDP. Similarly, every 100 incidents of bureau visits are associated with a 0.034 percent increase. The substantive significance is better seen by interpreting that number in concrete terms. In 2005, the average public security expenditure as a share of provincial GDP is 0.64 percent across all provinces. The figure of the Jiangxi province $(0.6279)$ was closest to that number, and it recorded 873 bureau-visit petitions related to water pollution. Had the Jiangxi province received 100 more bureau-visit petitions, its government would have spent 0.6619 percent of its GDP on the PSP. Consider- 
Table 1 Estimates of the Effects of Petitions on Provincial Governments' Repression Expenditure

\begin{tabular}{|c|c|c|c|c|}
\hline Estimation Strategy & & $2 \mathrm{SL}$ & & \\
\hline Dependent Variable & & PSPE/ & GDP & \\
\hline & (1) & (2) & (3) & (4) \\
\hline Letter-writing ${ }_{t-1}$ & $\begin{array}{c}0.012^{*} \\
(0.007)\end{array}$ & & $\begin{array}{l}0.008^{* * * *} \\
(0.002)\end{array}$ & \\
\hline Bureau-visit $t_{t-1}$ & & $\begin{array}{l}0.030^{* * *} \\
(0.011)\end{array}$ & & $\begin{array}{l}0.034^{* * * *} \\
(0.011)\end{array}$ \\
\hline Log GDP per cap & $\begin{array}{l}-0.453^{* * *} \\
(0.149)\end{array}$ & $\begin{array}{l}-0.165^{* *} \\
(0.079)\end{array}$ & $\begin{array}{l}-0.381 * * * \\
(0.074)\end{array}$ & $\begin{array}{l}-0.163^{*} \\
(0.087)\end{array}$ \\
\hline Population density & $\begin{array}{l}-0.002 \\
(0.001)\end{array}$ & $\begin{array}{c}0.001^{*} \\
(0.000)\end{array}$ & $\begin{array}{c}0.000 \\
(0.000)\end{array}$ & $\begin{array}{c}0.000 \\
(0.000)\end{array}$ \\
\hline Growth & & & $\begin{array}{l}-0.116 \\
(0.132)\end{array}$ & $\begin{array}{l}-0.050 \\
(0.150)\end{array}$ \\
\hline Population & & & $\begin{array}{l}-0.043^{* *} \\
(0.021)\end{array}$ & $\begin{array}{c}0.028 \\
(0.021)\end{array}$ \\
\hline Crime rate $_{t-1}$ & & & $\begin{array}{l}-2.978^{* * *} \\
(0.972)\end{array}$ & $\begin{array}{l}-0.017 \\
(0.614)\end{array}$ \\
\hline $\mathrm{FDI}_{\mathrm{t}-1}$ & & & $\begin{array}{l}-0.044^{* * *} \\
(0.014)\end{array}$ & $\begin{array}{l}-0.001 \\
(0.004)\end{array}$ \\
\hline CPI change & & & $\begin{array}{l}-0.003 \\
(0.003)\end{array}$ & $\begin{array}{l}-0.002 \\
(0.004)\end{array}$ \\
\hline Unemployment $_{t-1}$ & & & $\begin{array}{l}-0.012^{*} \\
(0.007)\end{array}$ & $\begin{array}{l}-0.023^{* * *} \\
(0.009)\end{array}$ \\
\hline Minority population share & & & $\begin{array}{l}0.026^{* * *} \\
(0.008)\end{array}$ & $\begin{array}{c}0.015^{*} \\
(0.009)\end{array}$ \\
\hline Politburo: secretary & & & $\begin{array}{l}-0.045^{*} \\
(0.023)\end{array}$ & $\begin{array}{l}-0.026 \\
(0.022)\end{array}$ \\
\hline Politburo: governor & & & $\begin{array}{c}0.003 \\
(0.042)\end{array}$ & $\begin{array}{c}-0.022 \\
(0.047)\end{array}$ \\
\hline Transition: secretary & & & $\begin{array}{l}-0.041^{* * *} \\
(0.013)\end{array}$ & $\begin{array}{l}-0.004 \\
(0.012)\end{array}$ \\
\hline Transition: governor & & & $\begin{array}{c}0.004 \\
(0.010)\end{array}$ & $\begin{array}{l}-0.010 \\
(0.012)\end{array}$ \\
\hline Tenure: secretary & & & $\begin{array}{c}0.003 \\
(0.002)\end{array}$ & $\begin{array}{l}-0.002 \\
(0.002)\end{array}$ \\
\hline Tenure: governor & & & $\begin{array}{l}-0.002 \\
(0.002)\end{array}$ & $\begin{array}{l}-0.002 \\
(0.003)\end{array}$ \\
\hline Constant & $\begin{array}{l}5.363^{* * *} \\
(1.630)\end{array}$ & $\begin{array}{l}1.804^{* *} \\
(0.814)\end{array}$ & $\begin{array}{l}4.429 * * * \\
(0.737)\end{array}$ & $\begin{array}{l}1.767^{*} \\
(0.925)\end{array}$ \\
\hline $\begin{array}{l}\text { Number of observations } \\
\mathrm{R}^{2}\end{array}$ & $\begin{array}{c}401 \\
0.692\end{array}$ & $\begin{array}{c}400 \\
0.857\end{array}$ & $\begin{array}{l}388 \\
0.858\end{array}$ & $\begin{array}{c}387 \\
0.810\end{array}$ \\
\hline First Stage & & & & \\
\hline Hydroelectricity $_{\mathrm{t}-2}$ & $\begin{array}{l}0.025^{* *} \\
(0.013)\end{array}$ & $\begin{array}{l}0.010^{* * *} \\
(0.002)\end{array}$ & $\begin{array}{l}0.041^{* * *} \\
(0.01)\end{array}$ & $\begin{array}{l}0.009 * * * \\
(0.003)\end{array}$ \\
\hline Wu-Hausman F Test & 10.75 & 10.06 & 20.65 & 20.26 \\
\hline Kleibergen-Paap F Stats & 3.94 & 16.26 & 17.79 & 12.08 \\
\hline
\end{tabular}

Notes: GE = Provincial Government's Total Expenditure; PSPE = Public Security Police Expenditure. All specifications contain province and year fixed effects, which are not reported but available from the authors. Standard errors are in parentheses. ${ }^{*} p<0.10 ;{ }^{* *} p<0.05 ;{ }^{* * *} p<0.01$. 


\begin{tabular}{|c|c|c|c|c|c|c|c|}
\hline \multicolumn{4}{|c|}{ 2SLS } & \multicolumn{4}{|c|}{ OLS } \\
\hline \multicolumn{4}{|c|}{ PSPE/GE } & \multicolumn{2}{|c|}{ PSPE/GDP } & \multicolumn{2}{|c|}{ PSPE/GE } \\
\hline (5) & (6) & (7) & (8) & (9) & (10) & (11) & (12) \\
\hline \multirow[t]{2}{*}{$\begin{array}{l}0.089^{* *} \\
(0.045)\end{array}$} & & $\begin{array}{l}0.071^{* * *} \\
(0.020)\end{array}$ & & $\begin{array}{c}0.000 \\
(0.000)\end{array}$ & & $\begin{array}{c}0.003 \\
(0.003)\end{array}$ & \\
\hline & $\begin{array}{l}0.229 * * * \\
(0.080)\end{array}$ & & $\begin{array}{l}0.310^{* * *} \\
(0.102)\end{array}$ & & $\begin{array}{c}0.001 \\
(0.001)\end{array}$ & & $\begin{array}{c}-0.003 \\
(0.012)\end{array}$ \\
\hline$-2.361^{* *}$ & -0.260 & $\begin{array}{c}-1.166^{*} \\
(0.655)\end{array}$ & $\begin{array}{c}0.873 \\
(0.801)\end{array}$ & $\begin{array}{l}-0.290^{* * * *} \\
(0.048)\end{array}$ & $-0.284^{* * *}$ & $\begin{array}{l}-0.321 \\
(0.421)\end{array}$ & $\begin{array}{c}-0.312 \\
(0.425)\end{array}$ \\
\hline $\begin{array}{l}(1.026) \\
-0.009\end{array}$ & $\begin{array}{l}(0.564) \\
0.007 * * *\end{array}$ & $\begin{array}{c}(0.655) \\
0.001\end{array}$ & $\begin{array}{c}(0.801) \\
0.002\end{array}$ & $\begin{array}{l}(0.048) \\
-0.000\end{array}$ & $\begin{array}{l}(0.048) \\
-0.000\end{array}$ & $\begin{array}{l}(0.421) \\
-0.002 * * *\end{array}$ & $\begin{array}{l}(0.425) \\
-0.002 * *\end{array}$ \\
\hline \multirow[t]{27}{*}{$(0.007)$} & $(0.002)$ & $(0.002)$ & $(0.003)$ & $(0.000)$ & $(0.000)$ & $(0.001)$ & $(0.001)$ \\
\hline & & $-3.425^{* * *}$ & $-2.950 * *$ & $-0.173^{*}$ & $-0.160^{*}$ & $-4.106^{* * *}$ & $-4.123 * * *$ \\
\hline & & $(1.177)$ & $(1.386)$ & $(0.094)$ & $(0.094)$ & $(0.819)$ & $(0.823)$ \\
\hline & & -0.017 & $0.643^{* * *}$ & 0.000 & 0.003 & $0.353^{* * *}$ & $0.360^{* * *}$ \\
\hline & & $(0.183)$ & $(0.193)$ & $(0.011)$ & $(0.011)$ & $(0.097)$ & $(0.097)$ \\
\hline & & $-20.839 * *$ & 5.714 & -0.302 & -0.098 & 2.706 & 3.506 \\
\hline & & $(8.662)$ & (5.679) & $(0.385)$ & $(0.375)$ & (3.353) & (3.291) \\
\hline & & $-0.376^{* * *}$ & 0.018 & -0.001 & 0.001 & 0.012 & 0.030 \\
\hline & & $(0.122)$ & $(0.041)$ & $(0.004)$ & $(0.003)$ & $(0.031)$ & $(0.025)$ \\
\hline & & 0.008 & 0.015 & -0.003 & -0.003 & 0.013 & 0.014 \\
\hline & & $(0.031)$ & $(0.035)$ & $(0.002)$ & $(0.002)$ & $(0.021)$ & $(0.021)$ \\
\hline & & 0.034 & -0.058 & $-0.008^{*}$ & $-0.009 *$ & $0.093 * *$ & $0.095 * *$ \\
\hline & & $(0.062)$ & $(0.082)$ & $(0.005)$ & $(0.005)$ & $(0.042)$ & $(0.043)$ \\
\hline & & $0.115^{*}$ & 0.011 & $0.023 * * *$ & $0.022 * * *$ & $0.088^{*}$ & $0.087^{*}$ \\
\hline & & $(0.067)$ & $(0.079)$ & $(0.005)$ & $(0.005)$ & $(0.047)$ & $(0.047)$ \\
\hline & & $-0.554 * * *$ & $-0.376^{*}$ & -0.003 & -0.002 & -0.094 & -0.076 \\
\hline & & $(0.207)$ & $(0.208)$ & $(0.013)$ & $(0.013)$ & $(0.114)$ & $(0.113)$ \\
\hline & & -0.407 & -0.638 & 0.001 & 0.003 & -0.131 & -0.116 \\
\hline & & $(0.376)$ & $(0.438)$ & $(0.025)$ & $(0.024)$ & $(0.215)$ & $(0.215)$ \\
\hline & & $-0.243 * *$ & 0.097 & $-0.016 * *$ & $-0.013^{*}$ & -0.002 & 0.007 \\
\hline & & $(0.115)$ & $(0.109)$ & $(0.007)$ & $(0.007)$ & $(0.065)$ & $(0.064)$ \\
\hline & & -0.030 & -0.152 & 0.005 & 0.003 & -0.015 & -0.014 \\
\hline & & $(0.088)$ & $(0.109)$ & $(0.007)$ & $(0.007)$ & $(0.061)$ & $(0.062)$ \\
\hline & & 0.031 & -0.011 & -0.001 & -0.001 & -0.002 & -0.004 \\
\hline & & $(0.022)$ & $(0.022)$ & $(0.002)$ & $(0.002)$ & $(0.013)$ & $(0.013)$ \\
\hline & & -0.017 & -0.012 & 0.000 & 0.001 & 0.010 & 0.011 \\
\hline & & $(0.022)$ & $(0.025)$ & $(0.002)$ & $(0.002)$ & $(0.015)$ & $(0.015)$ \\
\hline $28.313^{* *}$ & 1.986 & $14.999 * *$ & -9.808 & $2.647^{* * *}$ & $2.871^{* * *}$ & 4.381 & 5.275 \\
\hline (11.193) & $(5.805)$ & $(6.566)$ & $(8.564)$ & $(0.408)$ & $(0.434)$ & $(3.556)$ & $(3.815)$ \\
\hline 401 & 400 & 388 & 387 & 411 & 410 & 411 & 410 \\
\hline 0.361 & 0.696 & 0.706 & 0.612 & 0.937 & 0.932 & 0.865 & 0.863 \\
\hline $0.025^{* *}$ & $0.010 * * *$ & $0.041 * * *$ & $0.009 * * *$ & & & & \\
\hline$(0.013)$ & $(0.002)$ & $(0.01)$ & $(0.003)$ & & & & \\
\hline 12.42 & 14.63 & 23.97 & 25.34 & & & & \\
\hline 3.94 & 16.26 & 17.79 & 12.08 & & & & \\
\hline
\end{tabular}


ing that the GDP of this province in that year was 400 billion yuan, its government needs to spend 136 million yuan more on the PSP.

The intensity of petitions also matters, as evidenced by the larger effect of bureau visits than letter-writing. As was mentioned, bureau visits are usually more confrontational than sending in a complaint letter, supporting Implication 2. Note also that the 2SLS coefficients are larger than the OLS ones, indicating that the endogeneity problem causes a downward bias on the coefficients.

Specifications (7) and (8) differ from Specifications (3) and (4) in that the dependent variable is defined as Public Security Police Expenditure as a Share of Provincial Government's Total Expenditure, instead of as a Share of Provincial GDP. As may be seen from the table, the 2SLS estimates are robust to this alternative definition of the dependent variable.

Finally, note that in the first-stage regression, the coefficient on the instrument Hydroelectricity ${ }_{t-2}$ is statistically significant at 1 percent. Together with its plus sign, the coefficient indicates that hydroelectricity is positively linked with petitions related to water pollution. The Kleibergen-Paap F statistics of all full specifications exceed 10, further confirming that the instrument is not weak. The Wu-Hausman F statistics of these 2SLS specifications are all statistically significant, suggesting that we can reject exogeneity of waterpollution petitions in these specifications.

Next, consider the control variables. Owing to the page limit, we focus only on the 2SLS results of Table 1. First, the coefficient on Log GDP per Capita is negative and statistically significant in most specifications, indicating that richer provinces tend to spend less on coercion, even though their governments can afford the cost. This implies that social conflicts diminish as the economy reaches a high level of development. Economic development seems to enhance social stability, and when society becomes stable, political leaders invest less on their coercive apparatus.

The effect of Growth is negative, but statistically significant only in specifications using PSPE/GE as the dependent variable. The higher the economic growth rate, the less a provincial government would invest in the PSP. This result seems to suggest that economic growth is conducive to maintaining social stability.

The effect of Population size is mixed, as the sign and significance of the coefficient change from one specification to another. By contrast, the coefficient on Population Density is consistently positive in the full specifications, although it is statistically insignificant. 
Surprisingly, Lagged Crime Rate is negatively associated with the expenditure on PSP in all but the last specification. So, too, is the effect of Lagged FDI. The coefficient on CPI Change is not statistically significant in all specifications.

Interestingly, the expenditure on PSP decreases in the Lagged Unemployment Rate, as seen in specifications related to the PSPE/ GDP. The size of the effect is relatively small. A 1 percent increase in unemployment rate leads to a 0.012 percent decline in the PSP as a share of the provincial GDP. In theory, one would expect that unemployment fuels social grievances and instability, prompting political leaders to respond to the situation with more coercion. The contradictory outcome suggests two possibilities. The first possibility is that provincial leaders in China are quite benevolent such that they would deescalate their coercion when social grievances surge. The second possibility is that like the relationship between petitions and repression, the relationship between unemployment and repression is also endogenous. For example, only the most repressive provinces dare to slash public employment. Knowing that their political leaders are ruthless, laid-off workers are less willing to petition. As petitions do not increase along with unemployment, the provincial governments have no need to raise the law enforcement expenditure. Which possibility is closer to the reality in China requires further investigation, which is beyond the scope of this article.

Ethnic tensions play an important role in determining the level of expenditure with respect to coercion. Provinces occupied by a larger minority population tend to spend more on PSP. The coefficient on Minority Population Share is statistically significant in all but the last specification. The results suggest that ethnic problems may well be an important source of social conflicts in China.

Among all the political leadership variables, those related to party secretary seem to matter more. The expenditure on PSP is lower in provinces where the party secretary sits on the Politburo. In addition, Transition of Secretary has a negative effect on the expenditure on PSP, though the effect is significant only in specifications with letter-writing petitions. Substantively, this may imply a honeymoon effect; local citizens welcome a new leader and choose not to protest because they know that the new leader cannot be held responsible for the past misdeeds. An alternative interpretation is that local citizens are not sure how repressive a new secretary might be. As a result, they take a wait-and-see attitude. The dummy variables Transition of Governor and Politburo Governor have no significant 
effects. A possible explanation is that real political power, as many China observers understand, rests in the hands of the provincial party secretary, not of the governor.

While Table 1 evaluates Implications 1 and 2, Table 2 displays results concerning Implication 3. As discussed, the control of local coercive apparatus is not confined to provincial governments; central authorities also have the power to repress local unrest. We identify three major government institutions considered to be part of the coercive apparatus of the state.

Court and procuratorial organ. Local courts in China are not independent. Instead, many regard them as part of the coercive apparatus of local governments. The primary reason is that the latter controls the former's budget as well as personnel appointment. The PSP, the procuratorial organ, and the court, collectively known as gongjianfa, often work together under the auspices of the local government to form an effective bulwark against threats of social instability.

People's Armed Police Force. Unlike the public security police, the People's Armed Police Force (PAPF or wujin) is a paramilitary force that has a dual command structure. It is jointly led by the Central Military Commission and the State Council via the Ministry of Public Security. Organizationally, the PAPF has numerous subunits. One of them, which is known as the Internal Security Force (neiweibu), is led and funded by local authorities (Qiu and Tong 2004). In other words, provincial governments have the power to deploy at least part of the PAPF to maintain social order.

National defense agencies. Each provincial government is required to set aside a portion of its budget for national defense (Wang 1999). Local governments have limited influence on the agencies of national defense because these agencies are tightly controlled by the central authorities including the People's Liberation Army.

We run a similar regression analysis by using the provincial expenditure on the aforementioned coercive institutions as the dependent variable, ${ }^{12}$ Letter-Writing $_{t-1}$ and Bureau-Visit ${ }_{t-l}$. The 2SLS regression results are presented in Table 2. As may be seen from the table, the results are consistent with our theoretical expectations. In particular, for the court and procuratorial organ, which are wholly controlled by local governments, their expenditure would increase in proportion to the number of petitions filed by local resi- 
Table 2 2SLS Estimates of the Effects of Petitions on Other Repression Expenditures of Provincial Governments

\begin{tabular}{|c|c|c|c|c|c|c|}
\hline \multirow[t]{2}{*}{ Dependent Variabl } & \multicolumn{2}{|c|}{$\mathrm{CPE} / \mathrm{GE}$} & \multicolumn{2}{|c|}{ PAPFE/GE } & \multicolumn{2}{|c|}{$\mathrm{NDE} / \mathrm{GE}$} \\
\hline & (3) & (4) & (7) & (8) & (11) & $(12)$ \\
\hline Letter-writing $_{t-1}$ & $\begin{array}{l}0.038^{* *} \\
(0.017)\end{array}$ & & $\begin{array}{l}0.005^{* *} \\
(0.002)\end{array}$ & & $\begin{array}{l}-0.002^{* *} \\
(0.001)\end{array}$ & \\
\hline Bureau-visit ${ }_{\mathrm{t}-1}$ & & $\begin{array}{l}0.166^{* *} \\
(0.078)\end{array}$ & & $\begin{array}{c}0.021^{* *} \\
(0.009)\end{array}$ & & $\begin{array}{l}-0.008^{* *} \\
(0.004)\end{array}$ \\
\hline Log GDP per cap & $\begin{array}{l}-1.669^{* * *} \\
(0.548)\end{array}$ & $\begin{array}{l}-0.573 \\
(0.608)\end{array}$ & $\begin{array}{l}-0.186^{* *} \\
(0.084)\end{array}$ & $\begin{array}{c}0.013 \\
(0.099)\end{array}$ & $\begin{array}{l}-0.158^{* * * *} \\
(0.028)\end{array}$ & $\begin{array}{l}-0.210^{* * *} \\
(0.032)\end{array}$ \\
\hline Population density & $\begin{array}{l}y=0.008^{* * *} \\
(0.002)\end{array}$ & $\begin{array}{l}0.008^{* * *} \\
(0.002)\end{array}$ & $\begin{array}{l}-0.000 \\
(0.000)\end{array}$ & $\begin{array}{c}-0.000 \\
(0.000)\end{array}$ & $\begin{array}{l}-0.000 \\
(0.000)\end{array}$ & $\begin{array}{l}-0.000 \\
(0.000)\end{array}$ \\
\hline Growth & $\begin{array}{c}0.509 \\
(0.988)\end{array}$ & $\begin{array}{c}0.675 \\
(1.051)\end{array}$ & $\begin{array}{l}0.390^{* *} \\
(0.181)\end{array}$ & $\begin{array}{c}0.321^{*} \\
(0.175)\end{array}$ & $\begin{array}{l}-0.045 \\
(0.050)\end{array}$ & $\begin{array}{c}-0.067 \\
(0.056)\end{array}$ \\
\hline Population & $\begin{array}{c}-0.276^{*} \\
(0.153)\end{array}$ & $\begin{array}{c}0.079 \\
(0.146)\end{array}$ & $\begin{array}{c}-0.051^{*} \\
(0.028)\end{array}$ & $\begin{array}{c}0.020 \\
(0.023)\end{array}$ & $\begin{array}{l}-0.008 \\
(0.008)\end{array}$ & $\begin{array}{l}-0.025^{* * *} \\
(0.008)\end{array}$ \\
\hline Crime rate $e_{t-1}$ & $\begin{array}{l}-20.331 * * * \\
(7.241)\end{array}$ & $\begin{array}{l}-6.682 \\
(4.308)\end{array}$ & $\begin{array}{c}-0.917 \\
(0.909)\end{array}$ & $\begin{array}{c}0.985^{*} \\
(0.586)\end{array}$ & $\begin{array}{l}0.999 * * * \\
(0.364)\end{array}$ & $\begin{array}{c}0.242 \\
(0.230)\end{array}$ \\
\hline $\mathrm{FDI}_{\mathrm{t}-1}$ & $\begin{array}{l}-0.202 * * \\
(0.102)\end{array}$ & $\begin{array}{c}0.009 \\
(0.031)\end{array}$ & $\begin{array}{c}-0.020^{*} \\
(0.011)\end{array}$ & $\begin{array}{c}0.002 \\
(0.004)\end{array}$ & $\begin{array}{l}0.014 * * * \\
(0.005)\end{array}$ & $\begin{array}{l}0.003 * * \\
(0.002)\end{array}$ \\
\hline CPI change & $\begin{array}{c}0.045^{*} \\
(0.026)\end{array}$ & $\begin{array}{c}0.048^{*} \\
(0.027)\end{array}$ & $\begin{array}{l}-0.006 \\
(0.005)\end{array}$ & $\begin{array}{c}-0.003 \\
(0.004)\end{array}$ & $\begin{array}{c}0.002 \\
(0.001)\end{array}$ & $\begin{array}{c}0.002 \\
(0.001)\end{array}$ \\
\hline Unemployment $_{t-1}$ & $\begin{array}{c}0.009 \\
(0.052)\end{array}$ & $\begin{array}{c}-0.036 \\
(0.062)\end{array}$ & $\begin{array}{c}0.002 \\
(0.007)\end{array}$ & $\begin{array}{c}-0.002 \\
(0.007)\end{array}$ & $\begin{array}{l}-0.002 \\
(0.003)\end{array}$ & $\begin{array}{c}0.001 \\
(0.003)\end{array}$ \\
\hline $\begin{array}{l}\text { Minority } \\
\text { population share }\end{array}$ & $\begin{array}{c}0.005 \\
(0.056)\end{array}$ & $\begin{array}{c}-0.049 \\
(0.060)\end{array}$ & $\begin{array}{c}0.002 \\
(0.008)\end{array}$ & $\begin{array}{c}-0.007 \\
(0.008)\end{array}$ & $\begin{array}{l}-0.009 * * * \\
(0.003)\end{array}$ & $\begin{array}{c}-0.006^{*} \\
(0.003)\end{array}$ \\
\hline $\begin{array}{l}\text { Politburo: } \\
\text { secretary }\end{array}$ & $\begin{array}{c}-0.190 \\
(0.173)\end{array}$ & $\begin{array}{c}-0.098 \\
(0.158)\end{array}$ & $\begin{array}{l}-0.001 \\
(0.022)\end{array}$ & $\begin{array}{c}0.009 \\
(0.020)\end{array}$ & $\begin{array}{c}0.015^{*} \\
(0.009)\end{array}$ & $\begin{array}{c}0.011 \\
(0.008)\end{array}$ \\
\hline $\begin{array}{l}\text { Politburo: } \\
\text { governor }\end{array}$ & $\begin{array}{c}0.427 \\
(0.315)\end{array}$ & $\begin{array}{c}0.301 \\
(0.332)\end{array}$ & $\begin{array}{c}-0.022 \\
(0.053)\end{array}$ & $\begin{array}{c}-0.013 \\
(0.053)\end{array}$ & $\begin{array}{c}0.010 \\
(0.016)\end{array}$ & $\begin{array}{c}0.016 \\
(0.018)\end{array}$ \\
\hline $\begin{array}{l}\text { Transition: } \\
\text { secretary }\end{array}$ & $\begin{array}{c}-0.068 \\
(0.096)\end{array}$ & $\begin{array}{c}0.106 \\
(0.083)\end{array}$ & $\begin{array}{c}-0.008 \\
(0.012)\end{array}$ & $\begin{array}{c}0.015 \\
(0.010)\end{array}$ & $\begin{array}{c}0.008 \\
(0.005)\end{array}$ & $\begin{array}{c}-0.002 \\
(0.004)\end{array}$ \\
\hline $\begin{array}{l}\text { Transition: } \\
\text { governor }\end{array}$ & $\begin{array}{c}-0.008 \\
(0.074)\end{array}$ & $\begin{array}{c}-0.065 \\
(0.083)\end{array}$ & $\begin{array}{c}0.001 \\
(0.009)\end{array}$ & $\begin{array}{c}-0.008 \\
(0.010)\end{array}$ & $\begin{array}{c}0.000 \\
(0.004)\end{array}$ & $\begin{array}{c}0.004 \\
(0.004)\end{array}$ \\
\hline $\begin{array}{l}\text { Tenure: } \\
\text { secretary }\end{array}$ & $\begin{array}{c}0.026 \\
(0.019)\end{array}$ & $\begin{array}{c}0.004 \\
(0.017)\end{array}$ & $\begin{array}{c}0.002 \\
(0.002)\end{array}$ & $\begin{array}{c}-0.002 \\
(0.002)\end{array}$ & $\begin{array}{c}-0.002^{* *} \\
(0.001)\end{array}$ & $\begin{array}{c}-0.001 \\
(0.001)\end{array}$ \\
\hline $\begin{array}{l}\text { Tenure: } \\
\text { governor }\end{array}$ & $\begin{array}{l}-0.055^{* * *} \\
(0.019)\end{array}$ & $\begin{array}{l}-0.053^{* * *} \\
(0.019)\end{array}$ & $\begin{array}{c}-0.005^{*} \\
(0.002)\end{array}$ & $\begin{array}{c}-0.004 \\
(0.002)\end{array}$ & $\begin{array}{c}0.001 \\
(0.001)\end{array}$ & $\begin{array}{c}0.001 \\
(0.001)\end{array}$ \\
\hline Constant & $\begin{array}{l}16.523^{* * * *} \\
(5.494)\end{array}$ & $\begin{array}{c}3.183 \\
(6.492)\end{array}$ & $\begin{array}{l}2.294 * * * \\
(0.864)\end{array}$ & $\begin{array}{c}-0.123 \\
(1.029)\end{array}$ & $\begin{array}{l}1.739 * * * \\
(0.276)\end{array}$ & $\begin{array}{l}2.370^{* * *} \\
(0.347)\end{array}$ \\
\hline $\begin{array}{l}\text { Number of } \\
\text { observations } \\
\mathrm{R}^{2}\end{array}$ & $\begin{array}{c}387 \\
0.379\end{array}$ & $\begin{array}{c}386 \\
0.336\end{array}$ & $\begin{array}{c}320 \\
0.690\end{array}$ & $\begin{array}{c}319 \\
0.676\end{array}$ & $\begin{array}{c}387 \\
0.786\end{array}$ & $\begin{array}{r}386 \\
0.741\end{array}$ \\
\hline First Stage & & & & & & \\
\hline Hydroelectricity $t_{t-2}$ & $\begin{array}{l}20.041^{* * *} \\
(0.01)\end{array}$ & $\begin{array}{l}0.009^{* * *} \\
(0.003)\end{array}$ & $\begin{array}{l}0.044^{* * *} \\
(0.01)\end{array}$ & $\begin{array}{l}0.010^{* * *} \\
(0.003)\end{array}$ & $\begin{array}{l}0.041^{* * *} \\
(0.01)\end{array}$ & $\begin{array}{l}0.009 * * * \\
(0.003)\end{array}$ \\
\hline $\begin{array}{l}\text { Wu-Hausman } \\
\text { F Test } \\
\text { Kleibergen-Paap }\end{array}$ & 7.46 & 6.19 & 6.66 & 4.94 & 4.73 & 6.99 \\
\hline F Stats & 18.08 & 11.99 & 18.34 & 11.15 & 18.08 & 11.99 \\
\hline
\end{tabular}

Notes: $\mathrm{GE}=$ Provincial Government's Total Expenditure; $\mathrm{CPE}=$ Court and Procuratorial Organ Expenditure; PAPFE = People's Armed Police Force Expenditure; NDE = National Defense Expenditure. All specifications contain province and year fixed effects, which are not reported but available from the authors. Standard errors are in parentheses. ${ }^{*} p<0.10 ; * *<<0.05 ;{ }^{* * *} p<0.01$. 
dents. The coefficients on Letter-Writing - $_{t-1}$ and Bureau-Visit $t_{t-1}$ are statistically significant at 5 percent.

As for the regressions related to the expenditure on the PAPF, the coefficients on the variables of interest are both positive and statistically significant. This result should come as no surprise; although the PAPF is not organizationally subordinate to provincial governments, provincial governments nevertheless control and fund a crucial PAPF subunit, the Internal Security Force. As petitions rise, provincial governments would likely increase the budget for the Internal Security Force in the same way they do for the PSP expenditure.

Interestingly, in the last two specifications that use national defense expenditure as the dependent variable, the coefficients on both letter-writing and bureau visits are negative, suggesting that a provincial government would contribute less to the national defense budget if there were more petitions. This result is consistent with Implication 3: because a provincial government cannot deploy national defense agencies to clamp down on local unrest, it has no incentive to raise its contribution to the expenditure on such agencies in response to an increase of petitions. Despite their statistical significance, the size of the coefficients is quite small.

We run a number of additional tests to check the robustness of our main findings. The results are presented in Appendix C.

\section{Conclusion}

A salient characteristic of China's "fragmented authoritarianism" (Lieberthal and Oksenberg 1988) is its decentralized political structure; the center has granted considerable autonomy and power to local governments. Cai $(2008 \mathrm{~b}, 416)$ argues that the central government of China takes advantage of this decentralized system to advance its political interests, stating, "Decentralization shifts most of the responsibility of dealing with citizens' resistance to local governments, and the central government holds local governments accountable by assigning the responsibility directly to local leaders." Consequently, as he points out, "decentralization helps to protect the legitimacy of the central government" (Cai 2008b, 430).

In this article, we assert that local governments are not a passive player in the central government's blame game. The effectiveness of the blame game depends on whether citizens can hold lower-level officials accountable through the appeal system. Precisely because local officials are aware of the adverse political consequences when 
blamed, they have a strong incentive to respond to citizens' petitions strategically, instead of passively. They-in the same way the national leaders would do when challenged - turn to the repressive apparatus that they are able to control. It is widely reported that petitioners face brutal retaliation from local officials when they attempt to make their grievances heard by higher authorities. Our findings offer systematic evidence in support of previous anecdotal accounts. Remarkably, the petition cases we analyze are mostly local, nonregime threatening, or even nonpolitical in nature.

The central government may not perceive the rising number of petitions as a political threat. As Dimitrov (2013) observes, the upward trend may indicate that citizens still have faith in the petition system, which helps them redress grievances. The empirical results of this article, however, suggest that the central government should not stay complacent for two reasons. First, local officials are undermining the effectiveness of the petition system in their use of coercive means. The increasing prevalence of collective resistance in China shows that the existing grievance redress system is unable to meet aggrieved citizens' demands. Second, local governments' repression expenditure comes at a high cost. For one thing, China's spending on internal public security has reportedly surpassed national defense since 2010 (Hook 2011). If repression spurs more grievances and more protests, the authoritarian state of China may have to allocate more resources in the future to suppress nonregime threatening social demands than on productive economic activities. The vicious cycle between repression and petitions seems to have already come to the central authorities' attention. The recent abolition of a practice that ranks local officials by the number of petitions demonstrates that the central authorities are taking steps to alleviate the principal-agent problem embedded in the current petition system.

Stan Hok-wui Wong is assistant professor at the Chinese University of Hong Kong. His research interests center on authoritarian politics and democratization. His articles have appeared in Electoral Studies, China Review, and Journal of Contemporary Asia. He is also author of a forthcoming book, Electoral Politics in Post-1997 Hong Kong: Protest, Patronage, and the Media.

Minggang Peng is assistant professor in the Public Administration School at Guangzhou University. Peng received his $\mathrm{PhD}$ in political science from the Chinese University of Hong Kong. His research interests include public budgeting, financial management, and environmental politics in China. Contact him at pengminggang @gmail.com. 


\begin{tabular}{|c|c|c|c|c|}
\hline Variable & Mnemonic & Obs. & Mean & $\begin{array}{l}\text { Std. } \\
\text { Dev. }\end{array}$ \\
\hline \multicolumn{4}{|l|}{ Public Security Police Expenditure } & 0.28 \\
\hline Public Security Police Expenditure as a Share & & & & \\
\hline $\begin{array}{l}\text { of Provincial Government's Total Expenditure } \\
\text { Court and Procuratorial Organ Expenditure }\end{array}$ & PSPE/GE & 461 & 4.13 & 1.24 \\
\hline as a Share of Provincial GDP & CPE/GDP & 460 & 0.32 & 0.28 \\
\hline \multicolumn{5}{|l|}{ Court and Procuratorial Organ Expenditure as a } \\
\hline Total Expenditure & $\mathrm{CPE} / \mathrm{GE}$ & 460 & 2.07 & 0.92 \\
\hline $\begin{array}{l}\text { People's Armed Police Force Expenditure } \\
\text { as a Share of Provincial GDP }\end{array}$ & PAPFE/GDP & 344 & 0.03 & 0.03 \\
\hline $\begin{array}{l}\text { People's Armed Police Force Expenditure } \\
\text { as a Share of Provincial Government's }\end{array}$ & & & & \\
\hline Total Expenditure & PAPFE/GE & 344 & 0.16 & 0.12 \\
\hline $\begin{array}{l}\text { National Defense Agencies Expenditure } \\
\text { as a Share of Provincial GDP }\end{array}$ & NDE/GDP & 488 & 0.02 & 0.02 \\
\hline \multicolumn{5}{|l|}{ National Defense Agencies Expenditure } \\
\hline Total Expenditure & NDE/GE & 488 & 0.11 & 0.06 \\
\hline Water-Pollution Petition by Letter-Writing & & 521 & 13.87 & 22.79 \\
\hline Water-Pollution Petition by Bureau-Visit & & 519 & 3.93 & 3.93 \\
\hline Hydroelectricity Output & & 548 & 100.26 & 159.62 \\
\hline Log Provincial per Capita GDP & & 553 & 8.99 & 0.86 \\
\hline Provincial Population Density & & 553 & 363.84 & 463.56 \\
\hline Provincial Economic Growth Rate & & 552 & 0.17 & 0.08 \\
\hline Provincial Population & & 553 & 4.07 & 2.65 \\
\hline Provincial Crime Rate & & 484 & 0.06 & 0.02 \\
\hline Provincial Foreign Direct Investment & & 546 & 1.98 & 3.31 \\
\hline Provincial CPI Change & & 575 & 5.12 & 6.88 \\
\hline Provincial Unemployment Rate & & 567 & 3.34 & 1.06 \\
\hline \multicolumn{5}{|l|}{ Minority Population as a Share } \\
\hline of the Total Provincial Population & & 580 & 14.97 & 21.52 \\
\hline Provincial Party Secretary in Politburo & & 583 & 0.18 & 0.39 \\
\hline Provincial Governor in Politburo & & 583 & 0.03 & 0.16 \\
\hline Change of Provincial Party Secretary & & 583 & 0.21 & 0.41 \\
\hline Change of Provincial Governor & & 583 & 0.22 & 0.42 \\
\hline Provincial Party Secretary's Tenure & & 587 & 3.50 & 2.34 \\
\hline Provincial Governor's Tenure & & 587 & 3.13 & 2.03 \\
\hline
\end{tabular}




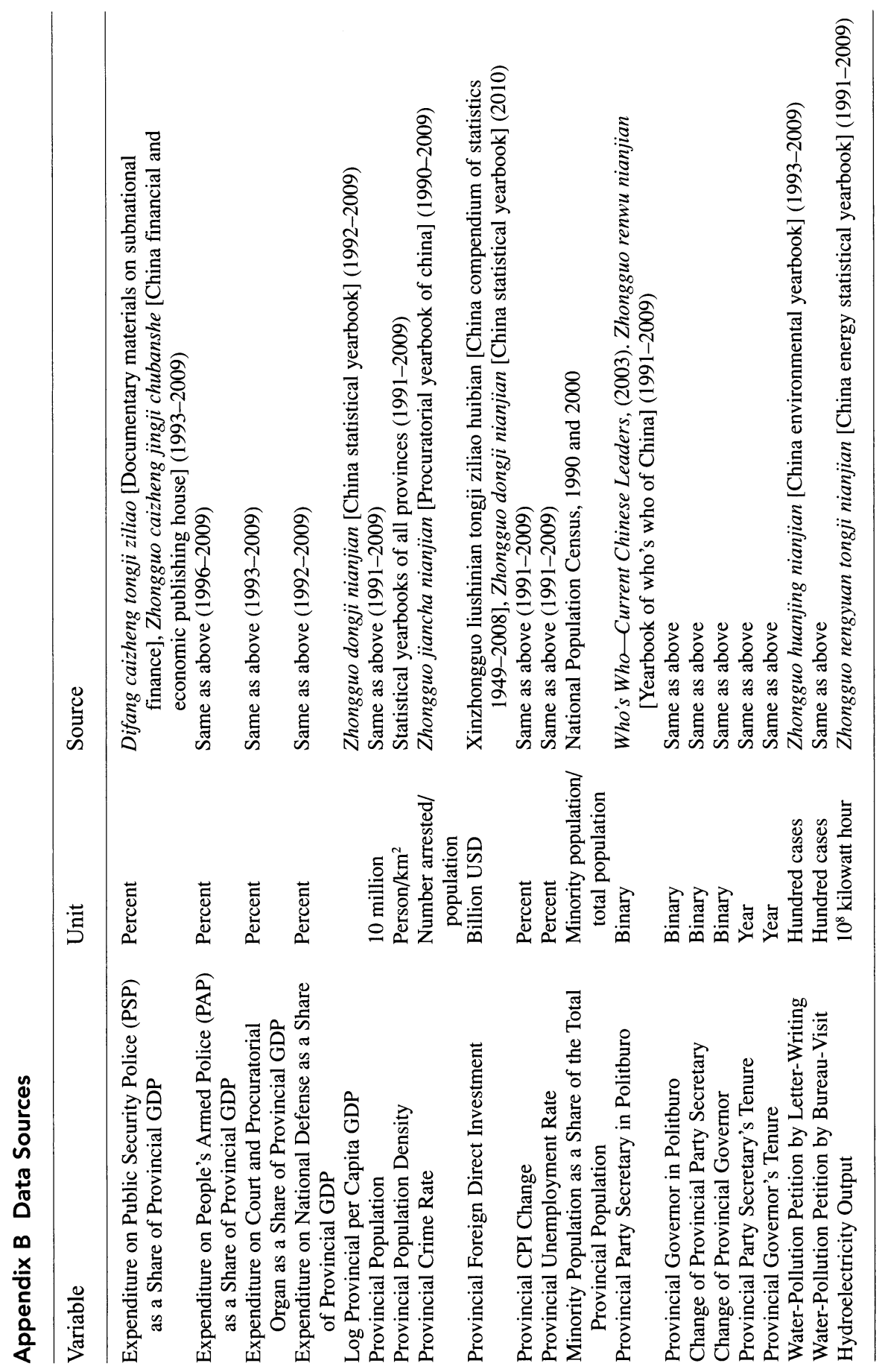




\section{Appendix C \\ Robustness Checks}

To ensure that the results presented in Table 1 are not driven by idiosyncratic shocks of a particular year, we rerun the 2SLS regressions by excluding individual years. The results are presented in Appendix $\mathrm{C} 1$. In the table, each displayed coefficient is a 2SLS estimate of a variable of interest (either Letter-Writing L-1 $_{t-1}$ or Bureau-Visit H-l $_{\text {) }}$ ) in a separate regression specification. As may be seen from the table, our estimates are robust to the exclusion of any given year, indicating that the results of Table 1 are unlikely driven by year-specific shocks.

Many Chinese petitioners would go to Beijing and Shanghai to file a petition against local officials. Yet coercive expenditures of these two cities may not reflect their local conditions. We rerun the above specifications, excluding Beijing and Shanghai from the sample. As may be seen from the last four rows of Appendix C2, the main results remain unchanged.

Thus far, we have used the absolute numbers of letter-writing and bureau-visit as the explanatory variables. As a robustness check, we adopt an alternative definition of letter-writing and bureau-visit by dividing their numbers by provincial population. The sign and significance of the 2SLS estimates, which are also displayed in Appendix $\mathrm{C} 2$, remain unchanged.

To investigate whether the effects identified above are truly driven by local governments' repressive response toward petitions, rather than that petitions affect the overall provincial budgets for reasons other than repression, we run an additional placebo test. We rerun the above 2 SLS regressions by replacing the coercion expenditures with two provincial-controlled expenditure items that are unrelated to repression. These are the provincial expenditure on public health and the provincial expenditure on pensions. If petitions are also positively correlated with the provincial expenditure on these items, this would suggest that petitions may be correlated with a trend of rising public expenditures. We can then cast doubt on the claim that petitions provoke provincial governments' coercive responses.

As may be seen from Appendix C3, none of the coefficients on the petition variables is statistically significant. Their signs are also different from the ones related to the PSP. They are negative, indicating that petitions tend to lower these socioeconomic expenditures. Note also that the hydroelectricity output remains significantly correlated with the petition variables in these 2 SLS regressions. The 


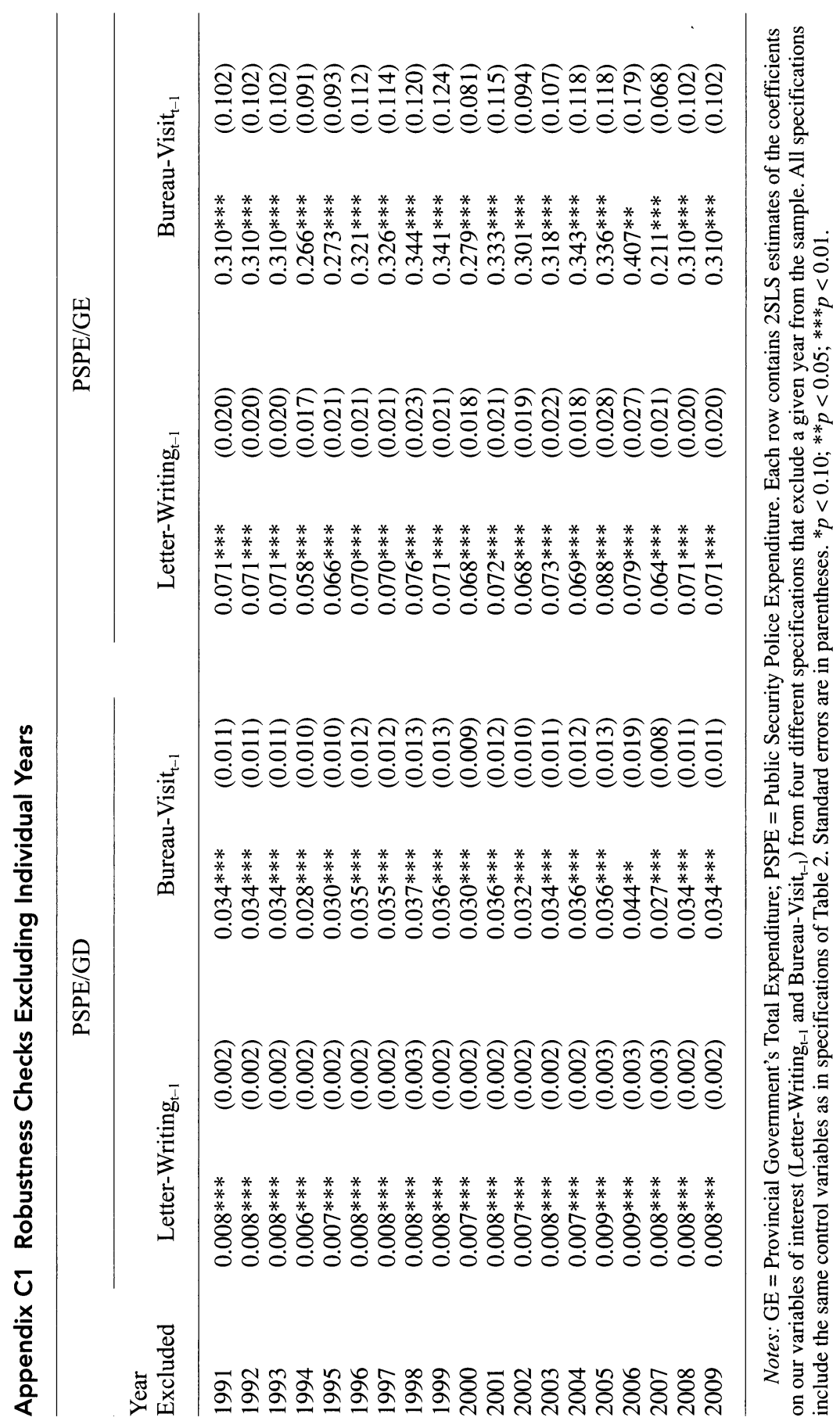




\section{Appendix C2 Robustness Checks Excluding Major Cities and Redefining Variables of Interest}

\begin{tabular}{|c|c|c|}
\hline Dependent Variable & PSPE/GDP & PSPE/GE \\
\hline Letter-Writing $_{t-1} /$ Log Population & $\begin{array}{l}0.001 * * * \\
(0.000)\end{array}$ & $\begin{array}{l}0.013 * * * \\
(0.004)\end{array}$ \\
\hline Bureau-Visit ${ }_{\mathrm{t}-1} /$ Log Population & $\begin{array}{l}0.006^{* * *} \\
(0.002)\end{array}$ & $\begin{array}{l}0.056^{* * *} \\
(0.019)\end{array}$ \\
\hline Letter-Writing $_{t-1}$ per Million Population & $\begin{array}{r}0.001^{*} \\
(0.000)\end{array}$ & $\begin{array}{c}0.008^{*} \\
(0.005)\end{array}$ \\
\hline Bureau-Visit $_{\mathrm{t}-1}$ per Million Population & $\begin{array}{l}0.002^{* *} \\
(0.001)\end{array}$ & $\begin{array}{l}0.021^{* *} \\
(0.009)\end{array}$ \\
\hline Letter-Writing $_{\mathrm{t}-1}$ (excluding Beijing and Shanghai) & $\begin{array}{l}0.009 * * * \\
(0.003)\end{array}$ & $\begin{array}{l}0.076^{* * *} \\
(0.023)\end{array}$ \\
\hline Bureau-Visit $_{\mathrm{t}-1}$ (excluding Beijing and Shanghai) & $\begin{array}{l}0.035^{* * *} \\
(0.011)\end{array}$ & $\begin{array}{l}0.298^{* * * *} \\
(0.097)\end{array}$ \\
\hline
\end{tabular}

Notes: GE = Provincial Government's Total Expenditure; PSPE = Public Security Police Expenditure. Each coefficient is a 2SLS estimate of our variables of interest (Letter-Writing $\mathrm{t}_{\mathrm{t}-1}$ and Bureau-Visit $\left.t_{t-1}\right)$ in a unique specification. All specifications include the same control variables as in specifications of Table 2. Standard errors are in parentheses. ${ }^{*} p<0.10 ;{ }^{* *} p<0.05 ;{ }^{* * *} p$ $<0.01$.

\section{Appendix C3 Placebo Tests: 2SLS Estimates of the Effects of Petitions on Other Provincial Expenditures}

\begin{tabular}{|c|c|c|c|c|}
\hline \multirow{2}{*}{$\begin{array}{l}\text { Dependent Variable } \\
\text { Second Stage }\end{array}$} & \multicolumn{2}{|c|}{ Public Health Expenditure } & \multicolumn{2}{|c|}{ Pensions Expenditure } \\
\hline & & & & \\
\hline Letter-Writing $_{\mathrm{t}-1}$ & $\begin{array}{c}-0.005 \\
(0.004)\end{array}$ & & $\begin{array}{c}-0.003 \\
(0.002)\end{array}$ & \\
\hline Bureau-Visit ${ }_{t-1}$ & & $\begin{array}{c}-0.025 \\
(0.018)\end{array}$ & & $\begin{array}{l}-0.01 \\
(0.006)\end{array}$ \\
\hline First Stage & & & & \\
\hline Hydroelectricity $_{\mathrm{t}-2}$ & $\begin{array}{l}0.032 * * * \\
(0.011)\end{array}$ & $\begin{array}{l}0.007 * * * \\
(0.003)\end{array}$ & $\begin{array}{l}0.048^{* * *} \\
(0.012)\end{array}$ & $\begin{array}{l}0.014 * * * \\
(0.003)\end{array}$ \\
\hline
\end{tabular}

results of Appendix C3 indicate no evidence that provincial governments indiscriminately raise their budgets in response to petitions. Petitions raise expenditures only of a specific kind - that is, coercive apparatus under a provincial government's control. In other words, the increase in the repression expenditures is a provincial government's intentional response toward petitions. 


\section{Notes}

We thank Barbara Geddes, Lianjiang Li, Wooyeal Paik, Susan Shirk, Hiroki Takeuchi, and Jing Vivian Zhan for commenting on previous drafts of this article. We are also grateful for two anonymous reviewers' constructive comments. All remaining errors are our own.

1. For simplicity, leaders of all these administrative units are called provincial leaders.

2. Note that some of the irregular taxes collected by local governments are illegal (Wedeman 2000).

3. In fact, the State Council issued a directive in 1998 stipulating that force should not be used to suppress peaceful petitions.

4. A prime example of ex ante preemption is the control of the Internet. The Chinese government has invested a significant amount of resources to strengthen its control of the Internet, which has become an important mobilization tool. Sensitive words are now filtered from the Web and cell phone messages (King, Pan, and Roberts 2013). Unorthodox political websites are made inaccessible. Human censors are hired to monitor bulletin boards and chat rooms. Because 42 percent of the online population access the Web in Internet cafés, many cities forced Internet cafés to install a networked video surveillance system that provides live video feed directly to local police offices (Deibert et al. 2010).

5. The reliability of statistical data in China always concerns researchers. We do not discount the possibility that provincial authorities attempt to reduce the petition numbers to avoid embarrassment. While the reported petition figures may be biased downward, the bias actually puts our arguments to a more severe test; if we are able to find a statistically significant effect of petitions on provincial governments' use of repression from the underreported data, we are confident that the true effect of petitions is likely greater.

6. See the official document "PRC's Ninth Five-Year National Economic and Social Development Plan and the Summary of the 2010 Visions and Targets" (Zhonghua renmin gongheguo guomin he shihui fazhan jiuwu jihua he 2010 nian yuanjing mubiao gangyao).

7. For details, see "Energy Development Plan for the Eleventh FiveYear Period" (nengyuan fazhan shiyiwu guihua) and "Renewable Energy Development Plan for the Eleventh Five-Year Period" (kezaisheng nengyuan fazhan shiyiwu guihua).

8. For instance, it is estimated that the sewage dumped into the Yangtze River in 2006 reached 4.5 million tons for every kilometer (Stone 2008).

9. For example, wealthy governments may be able to afford a larger security force.

10. For example, see "Provisional Measures on the Management of Financial Subsidies for Increasing Efficiency and Reforming Capacity of Rural Hydropower" (Nongcun shuidian zengxiao kuorong gaizao caizheng buzhu zijin guanli zanxing banfa), which was recently published by the Ministry of Finance and the Ministry of Water Resources. 
11. For instance, see "The Notice of the Ministry of Finance and the State Administration of Taxation on the Application of Low Value Added Tax Rates and Policies on Collecting Value Added Tax by the Simple Approach to Some Goods" (Guanyu bufen huowu shiyong zengzhishui dishuilv he jianyi banfa zhengshou zengzhishui zengce de tongzhi).

12. It is important to note that although there are central-level outlays for the PAPF and national defense agencies, the provincial expenditures that we examine here come strictly from provincial governments' budgets. Hence, they should reflect the decisions of provincial governments, rather than those of the central authorities.

\section{References}

Amnesty International. 2010. "Blind Chinese Human Rights Activist Remains Under Surveillance." September 13. www.amnesty.org/en/news-and -updates/blind-chinese-human-rights-activist-remains-under -surveillance-2010-09-13.

Bourchier, David. 1999. "Magic Memos, Collusion and Judges with Attitude: Notes on the Politics of Law in Contemporary Indonesia." In Law, Capitalism, and Power in Asia: the Rule of Law and Legal Institutions, ed. Kanishka Jayasuriya, 233-252. New York: Routledge.

Cai, Yongshun. 2008a. "Local Governments and the Suppression of Popular Resistance in China." The China Quarterly 193: 24-42.

- 2008b. "Power Structure and Regime Resilience: Contentious Politics in China." British Journal of Political Science 38, 3: 411-432.

Deibert, Ronald, John Palfrey, Rafal Rohozinski, Jonathan Zittrain, and Miklos Haraszti. 2010. Access Controlled: The Shaping of Power, Rights, and Rule in Cyberspace. Cambridge, MA: MIT Press.

Dimitrov, Martin A. 2013. "Vertical Accountability in Communist Regimes: The Role of Citizen Complaints in Bulgaria and China." In Why Communism Did Not Collapse: Understanding Authoritarian Regime Resilience in Asia and Europe, ed. Martin K. Dimitrov, 276-300. New York: Cambridge University Press.

Duflo, Esther, and Rohini Pande. 2007. "Dams." The Quarterly Journal of Economics 122, 2: 601-646.

Economy, Elizabeth. 2004. The River Runs Black: The Environmental Challenge to China's Future. Ithaca: Cornell University Press.

- 2007. "The Costs of China's Environmental Crisis." Foreign Affairs 86, 5: 38-59.

Edin, Maria. 2003. "State Capacity and Local Agent Control in China: CCP Cadre Management from a Township Perspective." The China Quarterly 173: 35-52.

Fearnside, Philip M. 1988. "China's Three Gorges Dam: 'Fatal' Project or Step Toward Modernization?" World Development 16, 5: 615-630.

Fewsmith, Joseph. 2013. The Logic and Limits of Political Reform in China. New York: Cambridge University Press. 
Francisco, Ronald A. 1996. "Coercion and Protest: An Empirical Test in Two Democratic States." American Journal of Political Science 40, 4: 1179-1204.

Gallagher, Mary Elizabeth. 2011. Contagious Capitalism: Globalization and the Politics of Labor in China. Princeton, NJ: Princeton University Press.

Gandhi, Jennifer, and Adam Przeworski. 2007. "Authoritarian Institutions and the Survival of Autocrats." Comparative Political Studies 40, 11: 1279-1301.

Geddes, Barbara. 2005. "Why Parties and Elections in Authoritarian Regimes?" Paper presented at the annual meeting of the American Political Science Association, Washington, DC.

General Office of the State Council. 2006. "Zongti guihua: Sanxia kuqu de yanmo qingkuang” [Macro planning: Three Gorges Dam region's submersion situation]. January 2. www.gov.cn/ztzl/2006-01/02/content 145309.htm.

Goldstein, Steven M. 1994. "China in Transition: The Political Foundations of Incremental Reform." Communist and Post-Communist Studies 27, 1: 61.

Hook, Leslie. 2011. "Beijing Raises Spending on Internal Security." Financial Times, March 6. www.ft.com/cms/s/0/f70936b0-4811-11e0-b323 -00144feab49a.html\#axzz1XwE8qDze.

Huang, Yasheng. 1999. Inflation and Investment Controls in China: The Political Economy of Central-Local Relations During the Reform Era. New York: Cambridge University Press.

Jin, Hehui, Yingyi Qian, and Barry R. Weingast. 2005. "Regional Decentralization and Fiscal Incentives: Federalism, Chinese Style." Journal of Public Economics 89, 9: 1719-1742.

King, Gary, Jennifer Pan, and Margaret E. Roberts. 2013. "How Censorship in China Allows Government Criticism but Silences Collective Expression." American Political Science Review 107, 2: 326-343.

Lichbach, Mark Irving, and Ted Robert Gurr. 1981. "The Conflict Process: A Formal Model." Journal of Conflict Resolution 25, 1: 3-29.

Lieberthal, Kenneth. 1995. Governing China. New York: Norton.

Lieberthal, Kenneth, and Michel Oksenberg. 1988. Policy Making in China: Leaders, Structures, and Processes. Princeton, NJ: Princeton University Press.

Magaloni, Beatriz. 2006. Voting for Autocracy: Hegemonic Party Survival and Its Demise in Mexico. New York: Cambridge University Press.

- 2008. "Enforcing the Autocratic Political Order and the Role of Courts: The Case of Mexico." In Rule by Law: The Politics of Courts in Authoritarian Regimes, ed. Tom Ginsburg and Tamir Moustafa, 180-206. New York: Cambridge University Press.

Magee, Darrin. 2006. "Powershed Politics: Yunnan Hydropower Under Great Western Development." The China Quarterly 185: 23-41.

McCully, Patrick. 1996. Silenced Rivers: The Ecology and Politics of Large Dams. Atlantic Highlands, NJ: Zed Books. 
Mertha, Andrew. 2008. China's Water Warriors: Citizen Action and Policy Change. Ithaca: Cornell University Press.

Michelson, Ethan. 2007. "Climbing the Dispute Pagoda: Grievances and Appeals to the Official Justice System in Rural China." American Sociological Review 72, 3: 459-485.

Minzner, Carl F. 2009. "Riots and Cover-Ups: Counterproductive Control of Local Agents in China." University of Pennsylvania Journal of International Law 31: 53-124.

Moustafa, Tamir. 2007. The Struggle for Constitutional Power: Law, Politics, and Economic Development in Egypt. New York: Cambridge University Press.

Nanfang Zhoumo. 2011. “China's Dams in Crisis?” July 7. http://nf.nfdaily .cn/epaper/nfzm/content/20110707/ArticleC150.

O'Brien, Kevin J., and Lianjiang Li. 2004. "Suing the Local State: Administrative Litigation in Rural China." The China Journal 51: 75-96.

- 2006. Rightful Resistance in Rural China. New York: Cambridge University Press.

Paik, Wooyeal. 2012. "Economic Development and Mass Political Participation in Contemporary China: Determinants of Provincial Petition (Xinfang) Activism, 1994-2002." International Political Science Review 33, 1: 99-120.

Peerenboom, Randall. 2003. "A Government of Laws: Democracy, Rule of Law and Administrative Law Reform in the PRC." Journal of Contemporary China 12, 34: 45-67.

Qiu, Bo-Hao, and Tong Yi-Hong. 2004. "Zhonggong wujing zai qi quojia anquan zhong de jiaose fenxi" [The role of armed police in the national security of China]. Fu Hsing Kang Academic Journal 81: 77-99.

Radio Free Asia. 2011. "Zhejiang Petitioners Brutalized in Beijing, Fozhou Female Villager Hospitalized." May. www.rfa.org/mandarin/yataibao dao/zj-05032011112914.html.

Rasler, Karen. 1996. "Concessions, Repression, and Political Protest in the Iranian Revolution." American Sociological Review 61, 1: 132-152.

Stone, Richard. 2008. "Three Gorges Dam: Into the Unknown." Science 321, 5889: 628-632.

Tarrow, Sidney. 2011. Power in Movement: Social Movements and Contentious Politics. New York: Cambridge University Press.

Tsui, Kai-yuen, and Youqiang Wang. 2004. "Between Separate Stoves and a Single Menu: Fiscal Decentralization in China." The China Quarterly 177: 71-90.

Wang, Shaoguang. 1999. "The Military Expenditure of China, 1989-1998." . 2005. "The Political Logic of Fiscal Transfers in China." Global Development Network.

Wedeman, Andrew. 2000. "Budgets, Extra-Budgets, and Small Treasuries: Illegal Monies and Local Autonomy in China." Journal of Contemporary China 9, 25: 489-511. 
Whiting, Susan H. 2006. Power and Wealth in Rural China: The Political Economy of Institutional Change. Cambridge: Cambridge University Press.

Wintrobe, Ronald. 1998. The Political Economy of Dictatorship (Vol. 6). Cambridge: Cambridge University Press.

Wong, Stan Hok-wui, and Hiroki Takeuchi. 2013. "Economic Assistance, Central-Local Relations, and Ethnic Regions in China's Authoritarian Regime.” Japanese Journal of Political Science 14, 1: 97-125.

Xinhua Net. 2003a. "Yangtze Fleets Set Sail to Sea After Filling the ThreeGorges Reservoir." June 19. http://big5.xinhuanet.com/gate/big5/www .cq.xinhua.org/threegorges/2003-06/19/content_623550.

_. 2003b. "Should Petitioners Be Penalized?" April 16. http://news .xinhuanet.com/focus/2003-04/16/content_833579.

Xinhua News Agency. 2010. "Sanxia baiwan yimin wancheng anzhi kuqu mai xiang zhifu xinzhengtu" [Million of Three Gorges migrants relocated dam region makes strides to prosperity]. September 17. http://news.xinhuanet.com/society/2010-09/17/c1 2579112.htm.

Zhan, Jing V. 2009a. "Decentralizing China: Analysis of Central Strategies in China's Fiscal Reforms." Journal of Contemporary China 18, 60: 445-462.

. 2009b. "Undermining State Capacity: Vertical and Horizontal Diffusions of Fiscal Power in China." Asian Politics and Policy 1, 3: 390-408.

Ziegenhagen, Eduard A. 1986. The Regulation of Political Conflict. New York: Praeger. 


\section{LYNNE RIENNER PUBLSHERS}

4TH EDITION

Understanding Contemporary China

Robert E. GAMER, EDITOR

PRAISE FOR THE PREVIOUS EDITIONS:

CC $T$ eading readers almost painlessly 1 through an extensive tour of modern China's events and issues, this anthology is well planned and, with its

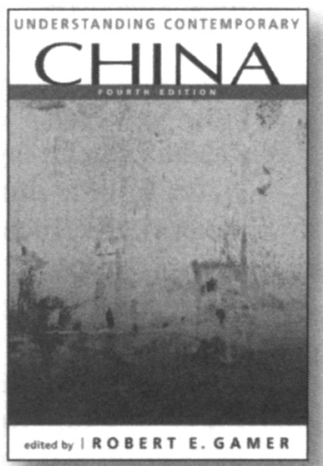
extensive bibliographies at the end of each chapter, a useful guide to deeper study as well as a rich resource for acquainting readers with China."-Mary Karen Solomon, Education About Asia

The new edition of Understanding Contemporary China has been thoroughly revised to reflect a half-decade of significant events and trends, both domestically and in the international arena. The result is an accessible, well-grounded exploration of the most crucial issues affecting China today.

Contents: Introduction-R.E. Gamer. China: A Geographic Preface-S.W. Toops. The Historical Context-R. Murphey. Chinese Politics-R.E. Gamer. China's Economy-S.Y. Tong and J. Wong. China Beyond the Heartland-R.E. Gamer. International Relations-R.E. Gamer. Population Growth and Urbanization-M. Rong. China's Environmental Problems-R.L. Edmonds. Family, Kinship, Marriage, and Sexuality-X. Zang. Women and Development-L. Bossen. Religion-H. Chan and A.Y.C. King. Literature and Popular Culture-C.A. Laughlin. Trends and Prospects-R.E. Gamer.

$2012 / 499$ pages $\cdot \mathrm{pb} \$ 27.50$

CELEBRATING 31 YEARS OF INDEPENDENT PUBLISHING 1800 30TH ST., SUITE 314 • BOULDER, CO 80301 - TEL: 303-444-6684 - www.rienner.com 